\title{
The Perez Ranch Project Reassessment of Four Archaeological Sites in South-central Bexar County, Texas
}

Jason D. Weston

Follow this and additional works at: https://scholarworks.sfasu.edu/ita

Part of the American Material Culture Commons, Archaeological Anthropology Commons, Environmental Studies Commons, Other American Studies Commons, Other Arts and Humanities Commons, Other History of Art, Architecture, and Archaeology Commons, and the United States History Commons

Tell us how this article helped you.

This Article is brought to you for free and open access by the Center for Regional Heritage Research at SFA ScholarWorks. It has been accepted for inclusion in Index of Texas Archaeology: Open Access Gray Literature from the Lone Star State by an authorized editor of SFA ScholarWorks. For more information, please contact cdsscholarworks@sfasu.edu. 
The Perez Ranch Project Reassessment of Four Archaeological Sites in Southcentral Bexar County, Texas

\section{Creative Commons License}

\section{(c) (1) \&}

This work is licensed under a Creative Commons Attribution-NonCommercial 4.0 International License 


\title{
The Perez Ranch Project
}

\section{Reassessment of Four Archaeological Sites in South-central Bexar County, Texas}

\author{
by \\ Jason D. Weston \\ with an Appendix by \\ Russell D. Greaves
}

Texas Antiquities Permit No. 3278

Steve A. Tomka

Principal Investigator

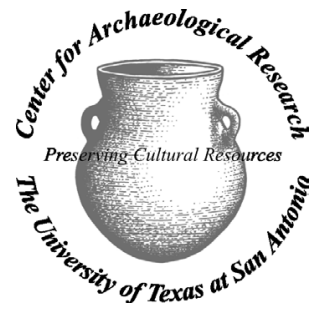

Center for Archaeological Research

The University of Texas at San Antonio

Archaeological Survey Report, No. 346 (C)2004 
A list of publications offered by the Center for Archaeological Research is available. Call (210) 458-4378; write to the Center for Archaeological Research, The University of Texas at San Antonio, 6900 N. Loop 1604 W., San Antonio, Texas 78249-0658; e-mail to car@lonestar.utsa.edu; or visit CAR's web site at http://car.utsa.edu. 


\section{Abstract:}

In anticipation of planned land developments, NICDAR, Inc. of San Antonio Texas contracted the Center for Archaeological Research at The University of Texas at San Antonio to conduct a reassessment and boundary definition of four archaeological sites, 41BX274, 41BX277, 41BX682, and 41BX988, located on or in the vicinity of the historic Perez Ranch. The archaeological investigations were carried out under Texas Antiquities Permit No. 3278 with Dr. Steve A. Tomka serving as Principal Investigator.

The investigations consisted of a surface survey of all sites, shovel testing and backhoe trenching at 41BX274, the Perez Ranch, shovel testing at 41BX988, the Laborer's Shack, and limited shovel testing outside the cemetery bounds at 41BX277, the Perez Family Cemetery and Chapel. The Dolores Crossing, 41BX682, a Spanish Colonial period ford of the Medina River was subject to surface survey only. Based on the surface and subsurface distributions of artifacts at 41BX274 41BX277, and 41BX988, new boundaries were defined, staked and recorded at these sites using Global Positioning System units. The size of site 41BX274 has been reduced by splitting it into two sites 41BX274 and 41BX274a. 41BX274a was split from the original site since it is a concentration of cultural materials located some 350 meters southeast of the nearest concentration of cultural materials at 41BX274. This isolated concentration of cultural materials has now been identified as 41BX274a. Based on surface survey and shovel testing, it also was recommended that the boundaries of site 41BX277 be slightly increased to include a light scatter of prehistoric cultural materials found around the cemetery. Furthermore, it was recommended that the site be identified as multicomponent, given the presence of both prehistoric and historic materials within its boundaries. Based on the distribution of cultural materials at 41BX682, the boundaries of the site have been reduced. Finally, no cultural materials have been identified at 41BX988, although the location of the historic crossing coincides with the crossing of the Medina River by Applewhite Road.

No cultural material was recovered from sites 41BX277 or 41BX682. Temporally diagnostic artifacts were recovered from the surface of sites 41BX274 and 41BX988. All cultural materials recovered in shovel tests at these two sites have also been retained. All artifacts are curated at the Center for Archaeological Research. 


\section{Table of Contents:}

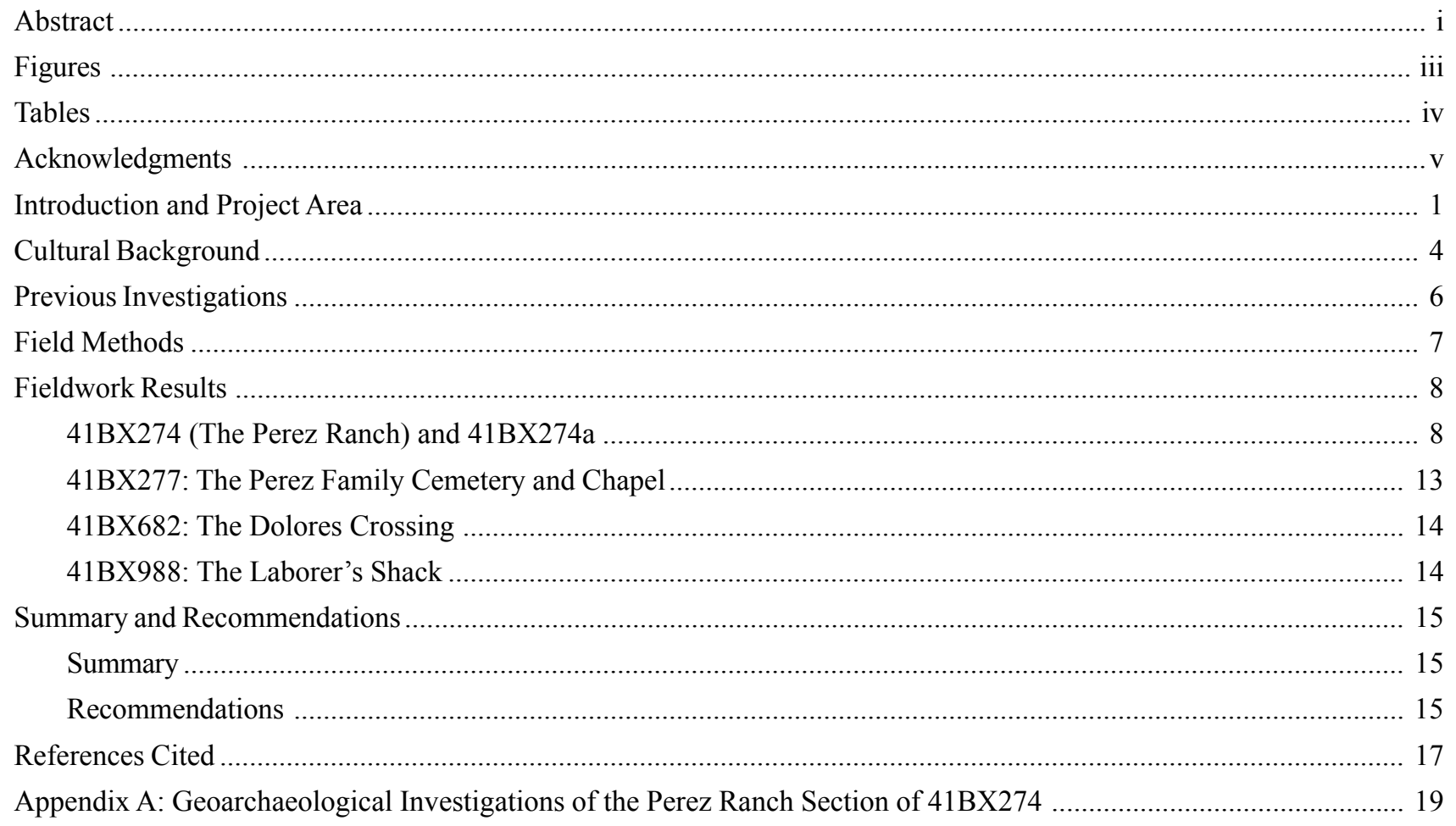




\section{Figures:}

Figure 1. Project area location map. ....................................................................................................... 1

Figure 2. Site map of 41BX274 with locations of 41BX274a, 41BX277 and 41BX682 ............................................

Figure 3. Site map of 41BX277, the Perez Family Cemetery and Chapel. .............................................................

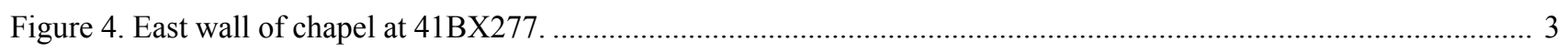

Figure 5. South wall of chapel at 41BX277. ................................................................................................. 3

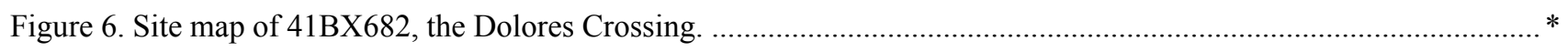

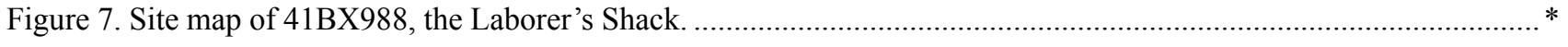

Figure 8. Selected artifacts recovered from sites 41BX274, 41BX274a, and 41BX988. ............................................. 9

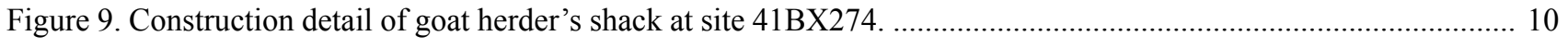

Figure 10. Identification of the iron kettle fragment recovered from 41BX274, Concentration C. ................................. 11

Figure 11. Shovel test locations at 41BX274 and 41BX274a. .................................................................................

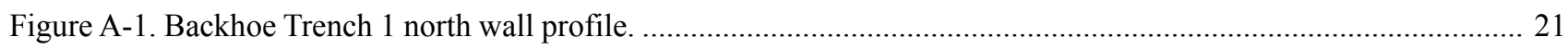

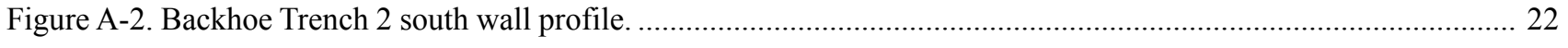

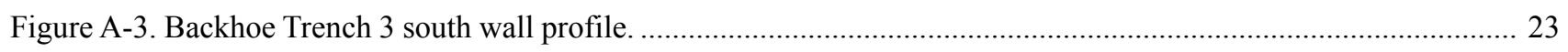

Figure A-4. Backhoe Trench 4 northwest wall profile. …...................................................................................... 24

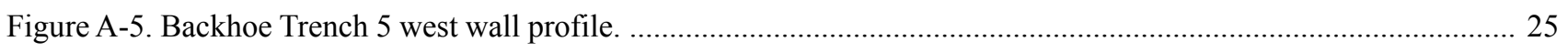

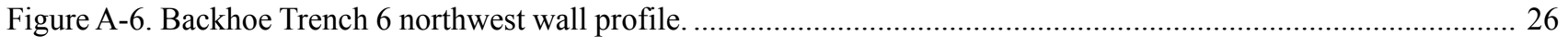

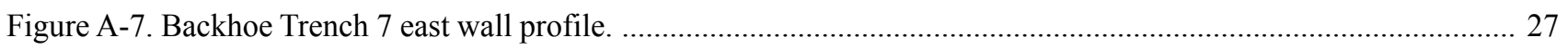

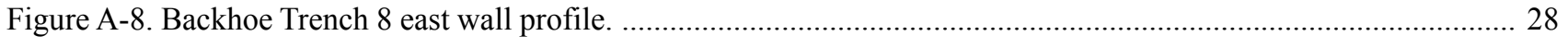

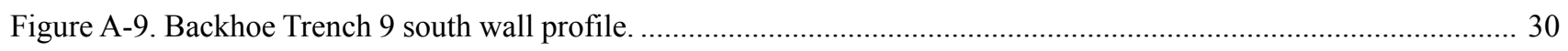

*Due to the sensitivity of archaeological site locations, site maps are located in a pocket at the back of this report. 


\section{Tables:}

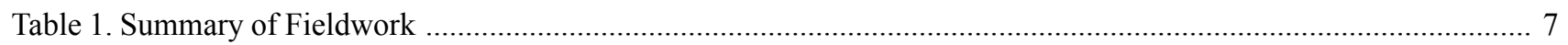

Table 2. UTM Coordinates for Boundary Markers at 41BX274, 41BX274a, 41BX277, 41BX682, and 41BX988 ........... *

Table 3. Distribution of Cultural Materials from Shovel Tests at 41BX988 ............................................................ 14

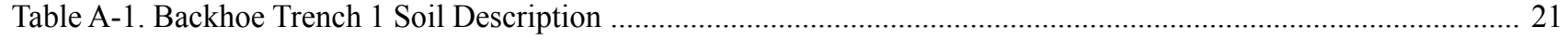

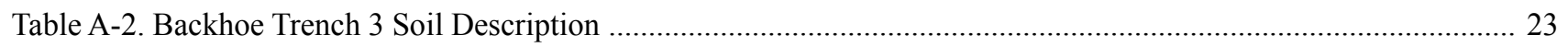

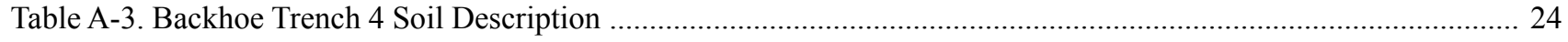

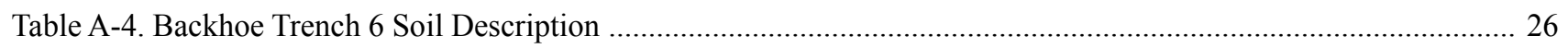

Table A-5. Backhoe Trench 9 Soil Description .............................................................................................................. 30

*Due to the sensitivity of archaeological site locations, the UTM coordinate table is located in a pocket at the back of this report. 


\section{Acknowledgments:}

The author would like to thank the landowners for the care and concern they have shown for the heritage of the property and Gerard R.C. Pastrano of GPP \& I, Inc. and Philip Martin Ross, Attorney and Counselor at Law, for their assistance and cooperation. Thanks also to the backhoe operators at Alamo Backhoe Service, Inc. for their excellent work. The hard work of the CAR field crew, Bruce Moses, Bryant Saner, Steven "Waldo" Troell, and Daniel Teague was indispensable. Appreciation as always to Russell Greaves for his geoarchaeological analysis, to Bruce Moses and Rick Young for drafting the graphics in this report, and to Johanna Hunziker for editing and formatting the final version. And finally, thanks also to Drs. Steve A. Tomka and Raymond P. Mauldin for their advice and direction during the project and the in-house review of this report. 



\section{Introduction and Project Area}

The archaeological survey project that is detailed in this report was initiated when NICDAR, Inc. of San Antonio Texas contracted with the Center for Archaeological Research (CAR) at The University of Texas at San Antonio to carry out the reassessment of four previously documented archaeological sites: 41BX274, 41BX277, 41BX682, and 41BX988. These sites are located between Applewhite Road and State Highway 16 in south-central Bexar County (Figure 1). The reassessment efforts of prehistoric and historic properties within the area had been requested to more precisely delineate the boundaries of the respective archaeological sites. A 100 percent pedestrian survey was conducted for each site and, through surface observations and subsurface investigations, the boundaries were defined and staked at all sites. A total of nine backhoe trenches and 95 shovel tests was excavated during the course of the project. Work was conducted under Texas Antiquities Permit No. 3278 on November 19-20 and December 2-5 and 19, 2003.
Due to the sensitivity surrounding archaeological site locations, all maps showing site locations and tables listing UTM coordinates are not included in the text. These materials are located in a pocket at the back of this report.

In the past, the area adjacent to the confluence of the Medina River and Leon Creek has played a key role in the history of San Antonio and the State beginning with the Perez Family Ranch (established 1795), one of the oldest ranches in the state and leading up to the Battle of Medina (1813). More recently, the planned construction of a Toyota manufacturing plant in south-central San Antonio/Bexar County is attracting significant development to this portion of the city/county. Much of this development is occurring in the vicinity of numerous historic and prehistoric properties, some of which are listed as State Archeological Landmarks (SALs). To avoid damaging significant archaeological sites, developers have initiated this reassessment effort to examine prehistoric

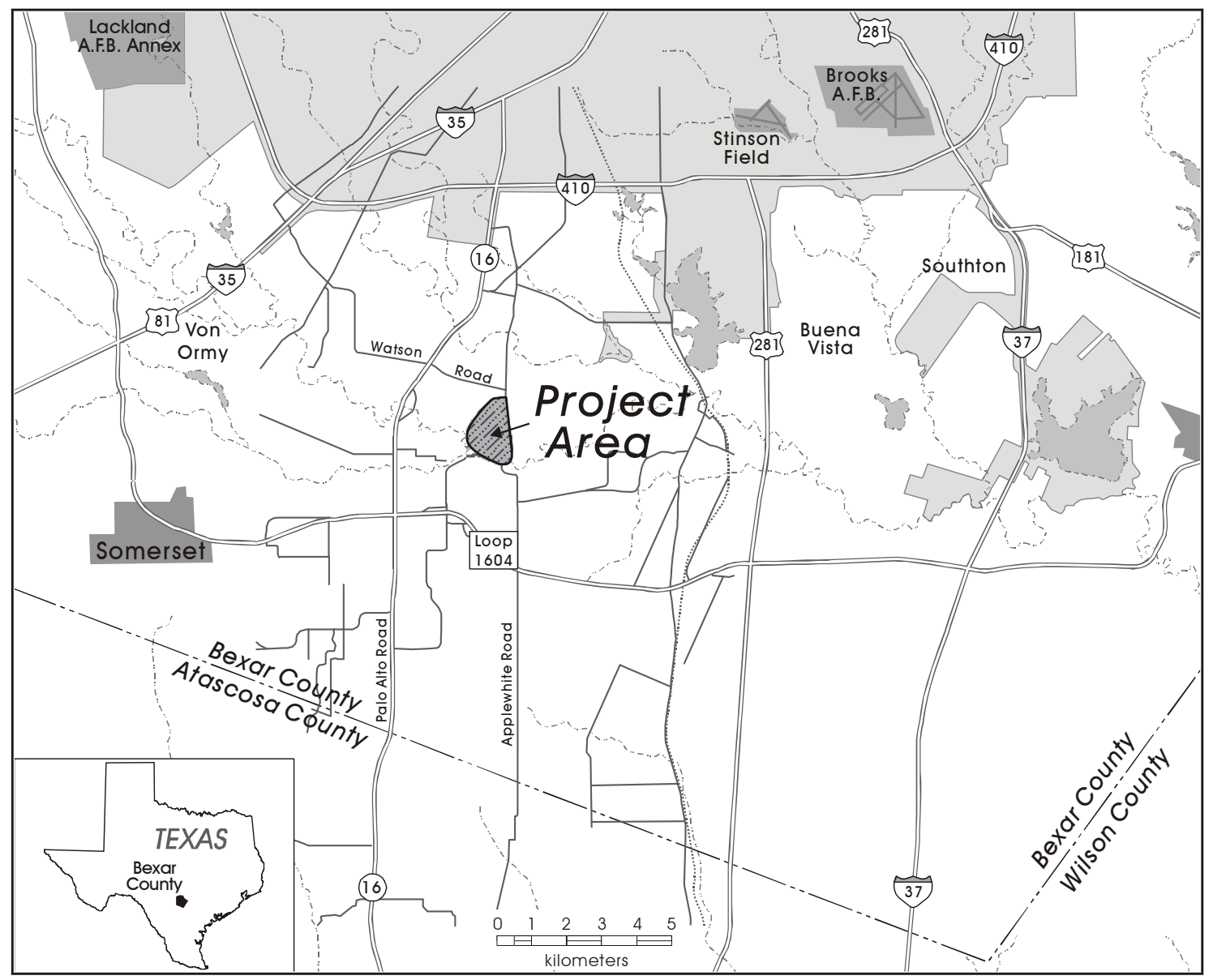

Figure 1. Project area location map. 
and historic sites within the project area. The work reported in this manuscript occurred within the same general context.

Site 41BX274 is a multicomponent site consisting of the Spanish Colonial to late 1800s Perez Ranch and a large, diffuse prehistoric component dating from the Early Archaic period to the Late Prehistoric period. The historic component represents the original Perez Family Ranch Headquarters (the ranch). The ranch and prehistoric materials are located on the high terrace above the Medina River west of Applewhite Road. The site was first recorded in 1974, and as originally documented, it extended westward on the north bank of the river for approximately 1.5 kilometers (Figure 2 , located at back of report).

The Perez Family Cemetery, site 41BX277, is approximately 150 meters northeast of the ranch location (Figures 2 and 3 , located at back of report). This site is located in a marginal upland setting above the Medina River floodplain. It was first identified in 1981 and visited in 1984. At the time of the visit, the structural remains consisted of a reconstructed stone/plaster chapel on the foundations of the original chapel. Burials are located to the west of the chapel and within the chapel proper (Figure 3). The earliest chapel may have been built in the early 1800s. The reconstructed chapel contains seven members of the Perez-Linn family (Figures 4 and 5).

Site 41BX682, the Dolores Crossing, is in the southeast portion of the project area (Figures 2 and 6, located at back of report). This was the main crossing used by the Perez Ranch and later the location of a one-lane concrete bridge crossing the Medina River today. As a part of Applewhite Road, the crossing still sees heavy use.

The final site is 41BX988. This location was once the site of a tenant farmer/laborer's shack that appears on aerial photos of the 1930s but burned down in the 1940s. This site sits in the northeast portion of the project area along Applewhite Road, 250-300 meters south of its junction with Watson Road (Figure 7, located at back of report). It was originally recorded as a historic scatter of ceramics, glass, and animal bone.

Much of the project area is dense mesquite and thorny brush with oak and juniper spread throughout. Open pasture is present in the eastern part of 41BX274 and around 41BX277. Site 41BX988 is entirely within a recently planted grass pasture. Site 41BX682, on the banks of the Medina River, is in a riparian setting. Heavily eroded areas are present along the edge of the high terrace above the Medina
River. The changes in vegetation communities affect the surface visibility within a single site and between sites.

Animals noted in the project area during the survey were domestic cattle (Bos taurus), wild hogs (Sus scrofa), whitetailed deer (Odocoileus virginianus), and a variety of bird species. Burrowing mammals, the rooting of wild hogs, and the well-worn trails of cattle and man-made road cuts appear to have impacted the surface and shallow subsurface deposits on most sites. 


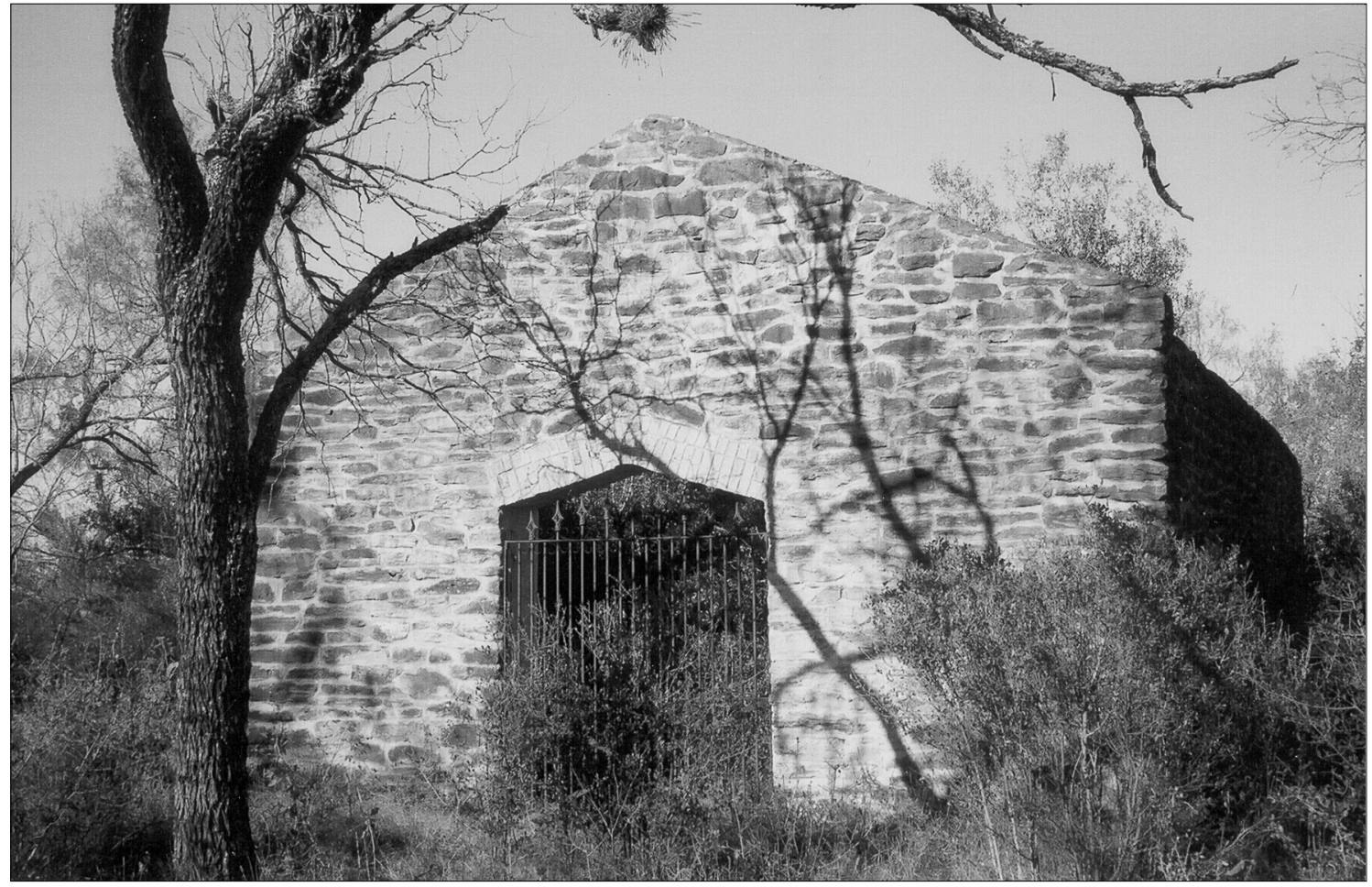

Figure 4. East wall of chapel at $41 B X 277$.

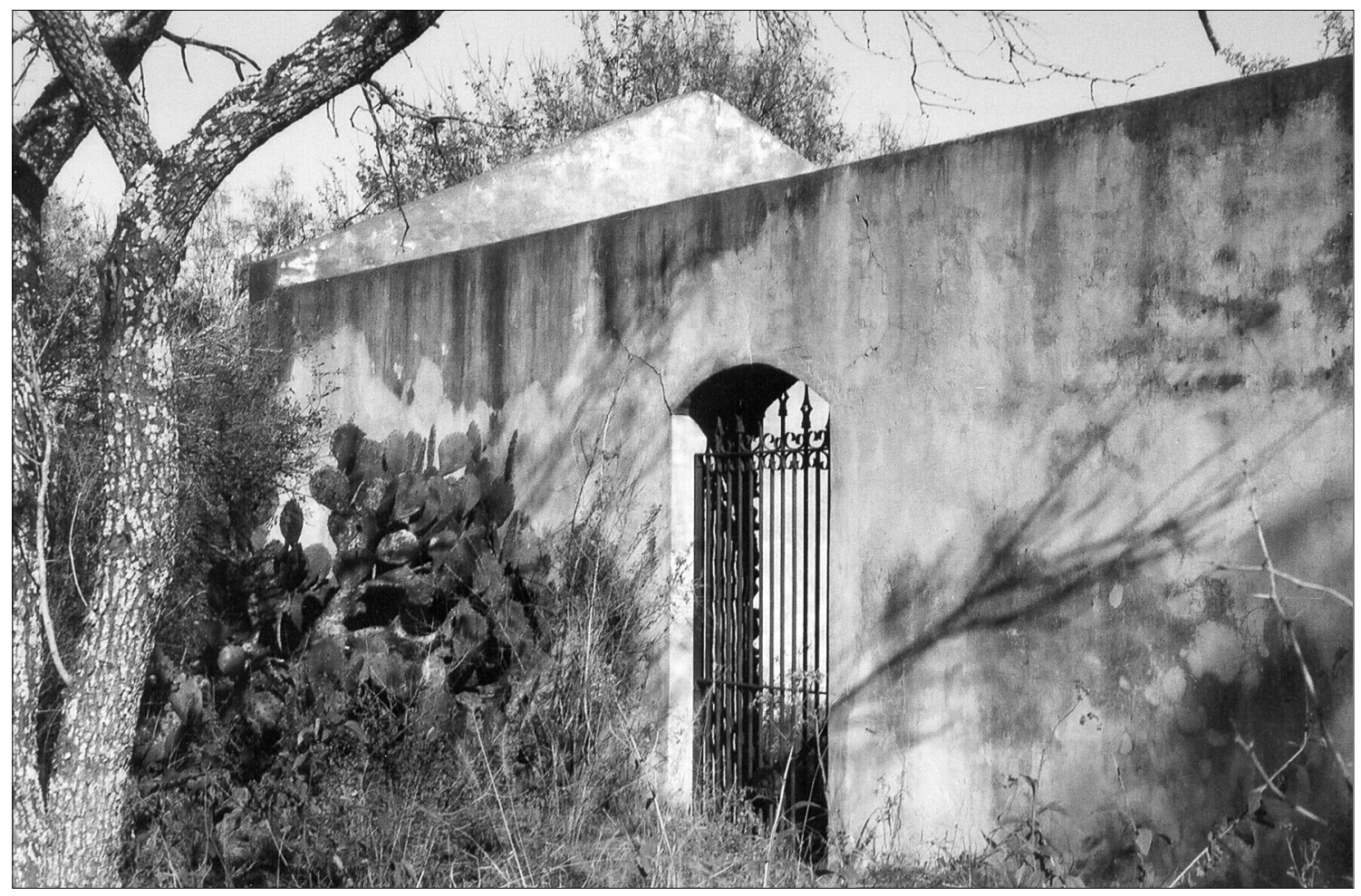

Figure 5. South wall of chapel at $41 B X 277$. 


\section{Cultural Background}

Prehistoric cultural materials from the Paleoindian, Early, Middle and Late Archaic, and Late Prehistoric periods have the potential to be present in the project area. Historic components in the project area date from the latter part of the Spanish Colonial period through the middle of the twentieth century. The following sections present a brief review of the prehistoric occupations and material cultures within the broader region and a brief history of the Perez Ranch.

\section{Paleoindian Period (1 1,500-8800 BP)}

The cultural material of the early portion of the Paleoindian period is characterized by two limited, uniform tool kits having widespread distributions. These tool kits are primarily recognized through their Clovis and Folsom projectile points (Cestaro et al. 2001:5-7; Collins 1995:381382; Mauldin and Nickels 2001:56-57). The Clovis material culture consists of fluted Clovis points, engraved stones, prismatic blades, bone and ivory tools and shaft straighteners (Mauldin and Nickels 2001:56). The Clovis hunter-gatherers were seen as having a highly generalized subsistence strategy. Clovis sites include kill localities, quarries/workshops, camps, burials and caches indicative of repeated returns to the same locations (Collins 1995:381-382). Succeeding Clovis, the Folsom tool kit consists of fluted Folsom points, end scrapers, and large thin bifaces. These tools indicate a hunting oriented subsistence pattern. Sites utilized by Folsom hunter-gatherers are kill localities, quarries/ workshops, and residential camps (Collins 1995:382).

The later portion of the Paleoindian period exhibits a slightly greater diversity of point forms and material culture. Late Paleoindian dart point types commonly recovered include Wilson, Golondrina, and Barber (Collins 1995:382).

\section{Early Archaic (8800-6000 BP)}

The Early Archaic, dating between 8800-6000 BP (Collins 1995:383) or 6500-3600 B.C. (Johnson and Goode 1994: 20-24), stone tool kit is significantly more diverse as are styles of dart points. Grinding and hammering stones are present as are Clear Fork and Guadalupe tools (both wood working tools) and a wide array of unifacial and bifacial tool forms (Collins 1995:383). Point styles and other tool forms become regionally constrained due in part to decreased mobility and population circumscription. Subsistence shifted away from big game hunting to a heavier reliance on plant foods (Collins 1995:383) and a variety of small to medium body sized fauna. Dozens of point styles are common to Central Texas during this period and they can be divided into three stylistic intervals: Angostura, Early Split Stem and Martindale-Uvalde (Collins 1995:383).

\section{Middle Archaic (6000-4000 BP)}

Bison had returned to the area before the end of the Early Archaic and were present in the first part of the Middle Archaic but withdrew again as the climate became drier (Collins 1995:384). In the Middle Archaic, lasting between 6000-4000 BP (Collins 1995:383), burned rock middens (earth ovens) become more common to allow the adequate processing of xeric plants such as sotol. The food sources drawn upon in the Early Archaic had declined in availability (Collins 1995:384). Bone and wood working tools became more numerous and the projectile point style intervals of the period were the Bell-Andice-Calf Creek, Taylor, and Nolan-Travis (Collins 1995:384).

\section{Late Archaic (4000-1200 BP)}

The climate grew wetter during the Late Archaic period (4000-1200 BP; Collins 1995:384; Decker et al. 2000:20$21,38)$. Burned rock midden use intensified in the Late Archaic and eventually peaked in the Late Prehistoric (Mauldin et al. 2003). Projectile point types from Late Archaic sites include Castroville, Edgewood, Ensor, Frio, Pedernales, and Montell, just to name a few (Collins 1995:384; Turner and Hester 1999). The Late Archaic also saw an increase in population (Collins 1995:385) and expanded trade networks (Johnson and Goode 1994:35-38).

\section{Late Prehistoric (1200-270 BP)}

The Late Prehistoric period begins with the Austin Phase heralded by the appearance of arrow points around $1200 \mathrm{BP}$ (Collins 1995:385) or A.D. 600 (Johnson and Good 1994:39). How much of a cultural change was introduced with this technology is unclear especially as the rest of the material record seems largely unchanged from the Late Archaic pattern (Collins 1995:385). Arrow point types diagnostic of the Austin Phase are Edwards and Scallorn (Turner and Hester 1999:212, 230). Significant cultural change began with the Toyah Phase. Bison once again returned to the area 
and ceramics were introduced as well as new cultural/ religious influences from Eastern Texas (Collins 1995:385; Johnson and Goode 1994:40-42). The Toyah Phase people on the Edwards Plateau shifted from intense plant gathering and small game hunting to less plant gathering and more bison hunting. Some of the ceramics produced during the Toyah Phase indicate a southwestern influence (Johnson and Goode 1994:40-42). This period ended with Spanish contact in Central Texas in the latter part of the seventeenth century (Chapa and Foster 1997:90-92; Collins 1995:386).

\section{Spanish Colonial Period to the Present: History of the Perez Ranch}

In south-central Texas the Historic period was initiated by European contact and immigration. At first, this contact was sporadic and intermittent but by the A.D. 1720s, permanent Spanish settlement was established at San Antonio in the form of a presidio with soldiers and settlers at mission San Antonio de Valero (Cox 1997:8). The establishment of the first official town in the San Antonio area by immigrants from the Canary Islands was finalized in A.D. 1734 (Cox 1997:10-11). The Spanish Colonial and later portions of the Historic period are marked by a demographic shift from a Native American population to a predominantly European population.

Juan Ignacio Perez, a grandson of original Canary Island immigrants to San Antonio de Bexar, was one of a handful of persons to establish ranches along the Medina River in the late-eighteenth to early-nineteenth centuries (McGraw and Hindes 1987:110-113). At this time, San Antonio de Bexar was still a small Spanish colony and immigrants to the area were building not only towns and ranches but an economy and society as well. Juan Ignacio Perez received a Spanish land grant in either 1754 or 1780 -the historic records are unclear as to the year. He received additional land in 1808 and was listed as one of the ranchers on the Medina River-Leon Creek area in 1812 (McGraw and Hindes 1987:110-111). This indicates that the Perez Ranch site was established at least as early as 1812 . The ranch at 41BX274 consisted of a stone house, a jacal and other outbuildings as well as corrals (McGraw and Hindes 1987:110). Today it is a 15 to 20 minute trip from downtown San Antonio to the Perez Ranch by automobile but by horse the roughly 10 to 12 mile trip would have taken a full day one way. This meant the ranch was perched on the edge of civilization and safety for its Spanish settlers and native laborers.
A successful rancher, Juan Ignacio Perez exercised significant political, economic and social influence and helped shape San Antonio's early history. While his economic base and family home was at the ranch, he owned the Commandencia of the presidio in San Antonio de Bexar which became known as the Governor's Palace after Perez served as ad interim governor of the Texas Territory from 1815 to 1817 (McGraw and Hindes 1987:110). Before his governorship he obtained recognition as a Captain in the Spanish Cavalry when he fought under General Joaquin de Arredondo to suppress rebels during the Battle of Medina in 1813 (McGraw and Hindes 1987:110). It was during this battle that the Dolores Crossing (41BX682) may have been fortified by the rebels before they were driven off. This indicates the possibility that Juan Ignacio Perez may not only have been fighting for Spanish Imperial rule but for the survival of his nearby ranch as well. The Camino Real para el Rio Grande was one of two roads running from San Antonio de Bexar to the south (Cox 1997:Figure 2-1) and likely crossed the Medina River at the Dolores Crossing.

In 1823 Juan Ignacio Perez, the prominent rancher, soldier and former governor, was laid to rest in the family chapel, site 41BX277. While his descendants lost land through the Republic of Texas court rulings in 1851 (McGraw and Hindes 1987:110-111), they maintained ownership of the lands abutting the north bank of the Medina River into the early part of the twenty-first century. Under the ownership of Perez's descendants, the property functioned as productive ranchland and farmland for nearly 200 years. 


\section{Previous Investigations}

Archaeological investigations in the project area began in 1981 with the Cultural Resources Assessment related to the aborted Applewhite Reservoir (McGraw and Hindes 1987). This work began just upstream of the Medina-Leon confluence and extended past Interstate 35 . Work in this area was carried out primarily by CAR which identified 78 sites. Additional surveys and site identifications have been made by Texas A\&M University and Southern Methodist University. The results of these investigations have not yet been published.

In 1987, CAR undertook testing at 41BX274, the Perez Ranch Site. The project involved extensive use of backhoe trenches, 1-x-1-m test units and several smaller 50-x-50$\mathrm{cm}$ units to assess the site. Findings showed that although most historic and Late Prehistoric materials occur on surface, Early Archaic materials and features, like burned rock concentrations, were buried to between 0.5-3 meters below surface (McGraw and Hindes 1987). Spanish Colonial ceramics were recovered from subsurface testing near the Goat Herder's shack (see Figure 2; Kay Hindes, personal communication 2003) and mid- to late-nineteenth-century historic materials were noted around the ranch house location.

Beginning in 2002, CAR undertook an intensive series of investigations on old Perez Family ranchland to the east of Applewhite Road between Leon Creek and the Medina River. Known as the Starbright Project, this work was done in preparation for the pending San Antonio Toyota Manufacturing Plant. Archaeological investigations included the reassessment of 15 sites discovered during the original Applewhite Reservoir survey and new surveys covering well over 400 acres of land not examined previously. The new surveys identified three new prehistoric sites (41BX1571, $41 \mathrm{BX} 1572$, and $41 \mathrm{BX} 1573$ ) and two early- to midtwentieth-century sites (41BX1574 and 41BX1575). The final report on the Starbright Project was pending as of the publication of the current report. In July and August of 2003, directly west of the current project area along the north bank of the Medina River, CAR conducted investigations in response to the planned creation and development of Medina River Park. This work reassessed nine previously known sites. Five were prehistoric sites, 41BX346A and B, 41BX347, 41BX348, 41BX350, and 41BX837. Two sites were historic, 41BX675 and 41BX857, and one has prehistoric and historic components, 41BX519. This work also identified four new sites; three prehistoric sites, 41BX1577, 41BX1579 and 41BX1580, and one multi- component historic and prehistoric site, 41BX1578 (Figueroa and Tomka 2004).

The general findings of both recent projects abutting the current project area show that most of the prehistoric sites and many of the historic sites are located along the bluff of the high terrace overlooking the Medina River. Nearly all are surface exposed to shallowly buried deposits, although a few exceptions do occur. In the case of previously identified sites along the terrace bluff, all have suffered severely from erosion in the past 20 years. 
The Perez Ranch Project

\section{Field Methods}

Consistent with the archaeological services to be performed, CAR proposed to undertake the following field tasks:

1) A 100 percent pedestrian survey of each site;

2) Shovel testing of sites 41BX274 and 41BX988;

3) Excavation of backhoe trenches on 41BX274 and inspection of cutbanks and arroyo walls for exposed deeply buried archaeological deposits;

4) The staking of site boundaries for all sites; and

5) The Global Positioning System mapping of boundary stakes on 41BX274, 41BX682, and 41BX988, and the fence (site limits) around 41BX277, the cemetery site.

To reassess sites 41BX274 and 41BX988, CAR archaeologists relocated each site using aerial photographs and field maps showing the location and outline of the sites as defined during the original survey. Once the sites were relocated, crews surveyed the sites by traversing the site areas along 15 -meter transects. Aerial photographs with clearly marked original site boundaries and new survey transects along with hand-held compasses were used to orient crewmembers along their routes. The pedestrian surveys extended at least 20 meters beyond the original site boundary to allow for any changes in original site size and mapping inconsistencies.

The distribution of surface artifacts were mapped during the pedestrian survey using Trimble Geo Explorer II Global Positioning System (GPS) units. GPS units were also used to establish current site boundaries. In the CAR laboratory, the GPS-mapped site boundaries were compared with site boundaries as they appeared during the original survey and site recording. Portions of the sites where the originally recorded artifact distributions extended beyond the currently observed distributions were examined using a combination of shovel testing and backhoe trenching. When no subsurface materials were encountered in areas that were formerly identified as part of the site, it was assumed that the materials noted during the original survey are no longer present and the site boundary was redrawn to exclude these areas. New areas where surface scatters, shovel tests, and backhoe trenches indicated the presence of cultural materials have been included in the current site boundaries.

A standardized form containing observations concerning site disturbance, vegetation, and estimated artifact counts was completed for each site. Diagnostic artifacts were collected, and their locations recorded with a GPS unit. In addition, sketch maps, showing site boundaries, shovel tests, collected items, areas of high artifact density, and physical features on the landscape, were produced. Archival quality $35-\mathrm{mm}$ black-and-white prints and color slides were made of all sites and artifacts where appropriate. Texas site forms have been prepared for all four of the revisited sites.

The shovel tests were $30-\mathrm{cm}$ diameter units excavated to a minimum depth of $60 \mathrm{~cm}$ or until the sterile substrate was encountered. Shovel tests were excavated in $10-\mathrm{cm}$ levels and all matrix was screened through $1 / 4$-inch hardware cloth. Observations on the shovel tests were recorded on standardized forms. All backhoe trenches were 5-8 meters long by 1.4 meters wide and 1.5 meters deep. Soil descriptions were made when pertinent and soil profiles were drawn for each trench. All artifacts recovered from shovel tests and backhoe trenches were returned to the CAR laboratory for processing and curation. All shovel test and backhoe trench locations were recorded using a GPS unit.

The aforementioned field strategy was employed in defining the current site boundaries on both 41BX274 and 41BX988. The definition of site boundaries for sites 41BX277 and 41BX682 was less complex. Site 41BX277 is a fenced-in family cemetery. Once the cemetery was relocated, the corners of the cemetery were mapped using GPS units. In the case of 41BX682, the Dolores Crossing of the Medina River, the site was relocated based on the description in the original Applewhite Reservoir report (McGraw and Hindes 1987). Table 1 summarizes the work performed at each site during this project.

Table 1. Summary of Fieldwork

\begin{tabular}{|c|c|c|c|c|}
\hline Site \# & Surface Survey & Backhoe Trenches & Shovel Tests & Boundary Markers \\
\hline 41BX274 & Yes & 9 & 84 & 13 \\
\hline 41BX277 & Yes & 0 & 3 & 4 fence posts \\
\hline 41BX682 & Yes & 0 & 0 & 4 \\
\hline 41BX988 & Yes & 0 & 8 & 4 \\
\hline
\end{tabular}




\section{Fieldwork Results}

\section{BX274 (The Perez Ranch) and 41BX274a}

The reassessment and site boundary definition of 41BX274 began with a 100 percent pedestrian survey of the entire site area. The survey located several (10) artifact concentrations. Following the survey, 84 shovel tests were dug across the site and nine backhoe trenches were excavated. Based on the results of this work, 41BX274 was divided into two separate sites and a portion of the site area was eliminated. The main site, 41BX274 consists of two principal components, an early-nineteenth-century component and a prehistoric component. The historic component was identified in Concentrations A, B and C. The prehistoric component is evident in Concentrations $\mathrm{D}$, E, F, G, H and J (see Figure 2). The second, smaller site 41BX274a (Figure 2), originally identified as Concentration I, contains both historic and prehistoric cultural materials.

\section{The Historic Component of 41BX274: The Perez Ranch Section}

Surface artifact Concentrations A, B and C, located in the north-central one-half of the site (Figure 2), are associated with the Perez Ranch itself. The ranch section of 41BX274 is roughly divided east-west by a fence. To the east is open pasture (once an agricultural field now gone fallow) and to the west dense brush, bedrock outcrops and eventually the drop-off of the high terrace. Overlying the light prehistoric scatter of debitage, cores, and fire-cracked rock (FCR) is the historic component. The historic deposit includes nineteenth-century wall rubble of the ranch house, ceramics and glass fragments from items such as plates and jars in addition to iron tools and cookware. Artifacts such as temporally diagnostic ceramics, iron, and glass were collected as representative samples.

Concentration A contained the largest artifact scatter including the large, sandstone rubble pile that once was the ranch house walls. Surface visibility in this area was 70 percent. A light scatter of debitage was noted on the surface. Ceramic sherd samples recovered during surface survey include English whiteware, edge ware, transfer ware, and Flow Blue, all dating to the first half of the nineteenth century (1800-1850; Figure 8, a-m). One sherd of utilitarian stoneware dates to the late nineteenth century (Anne Fox, personal communication 2003). Concentration I is a scatter of prehistoric lithics and historic artifacts. Previous testing in these areas identified low to very low densities of lithic debris and no features (McGraw and Hindes 1987:108-125).

Concentration B, located on a bedrock outcrop, consisted of late-nineteenth-century whiteware and glass and possible Spanish Colonial ceramics. Surface visibility ranged from 20 to 70 percent. A goat herder's shack is located in a road cut, just south of Concentration B (Figure 2). The shack itself is made of mesquite posts set into the ground in a type of palisade construction. It has two open entryways and two open windows. The roof is made of tin and nominal lumber, and all nails are wire cut. Used to patch a hole in the north wall is a wrought iron bed frame, possibly over 50 years old. The shed itself is clearly twentieth-century as indicated by the wire cut nails used in attaching lumber to the mesquite posts (see Figure 9).

Concentration C, with a surface visibility of only 10 to 20 percent, yielded a transfer ware sherd from the first half of the nineteenth century and a fragment of a cast iron pot (Figure 10a) identified as part of a tripod kettle (Anne Fox, personal communication 2003). This type of kettle was common in the Americas from the early-eighteenth into the late-nineteenth century (Tyler 1978:30-31). A comparison of existing types and varieties shows the closest similarity is to French Marmites (Figures 10a and 10b). English and Anglo-American kettles have a constricted neck and an everted rim, the French kettles and the piece recovered from 41BX274 have a straight neck and rim. This type of tripod kettle was common in Louisiana with documented orders placed as late as 1813 , by which time they were being made by the U.S. Office of Indian Trade Factory (The Engagé 1997:4). While the heavy kettles are more common at communities supplied by water transportation (The Engagé 1997:4), regular shipping was established between New Orleans and Texas by the 1830s (Henson 1996:43, 77-78). The availability of such a kettle would still have been rare but the Perez family would have had the resources to acquire such an item (McGraw and Hindes 1987:116). The kettles shown in Figure 10b are a one-quart, five-inch tall kettle and a six-quart, ten-inch tall kettle. The rim diameter of the six-quart kettle is estimated at 10 inches. Based on the curvature, the portion of the kettle recovered from Concentration C represents 17.5 percent of the total diameter (Figure 10a). This allows for an estimate of the diameter using a curvature template. The estimated diameter is 19 $\mathrm{cm}$ or approximately 7 inches. This would indicate a kettle smaller than six quarts and larger than one quart. The shape of the ears where the handle was attached is temporally 


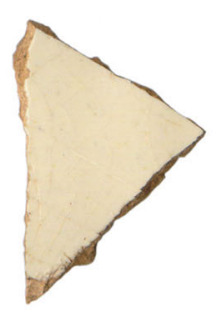

a

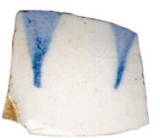

k

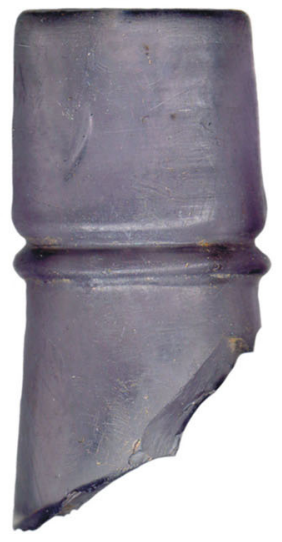

o

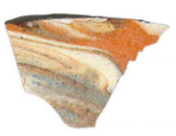

b

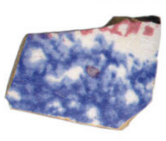

g

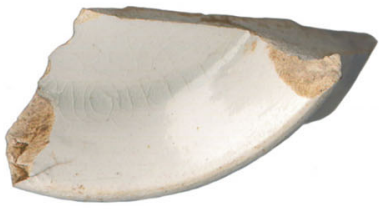

I

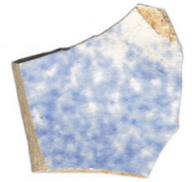

h

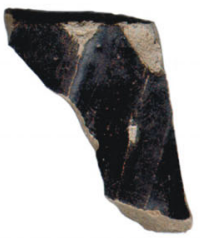

m

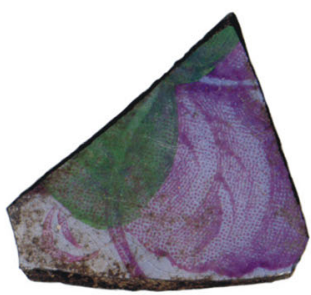

$\mathrm{n}$

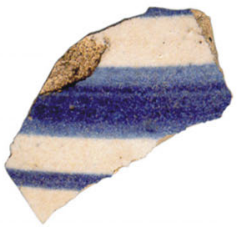

q

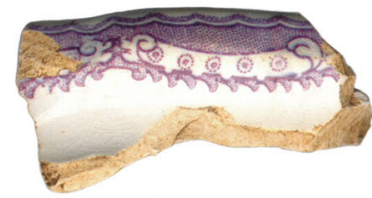

e

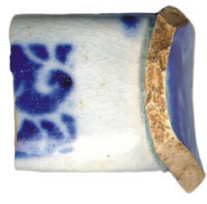

j

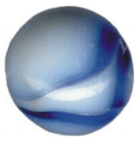

p

Figure 8. Selected artifacts recovered from sites 41BX274, 41BX274a, and 41BX988. a) tin-glazed ceramic; b) mocha banded slip; c) banded slip; d-e) transfer wares; f) blue feather edge; $g-h$ ) sponge ware; i-j) flow blue ware; k) hand-painted; 1) white earthenware base; m) stoneware; $n$ ) Hulme and Booth transfer ware; o) purple bottle neck; $\mathrm{p}$ ) swirl glass marble; $\mathrm{q}$ ) tin-glazed blue-on-white ; r) porcelain tea cup handle. [a-m from Concentration A, 41BX274; $n-0$ from 41BX274a; $\mathrm{p}-\mathrm{r}$ from 41BX988] 


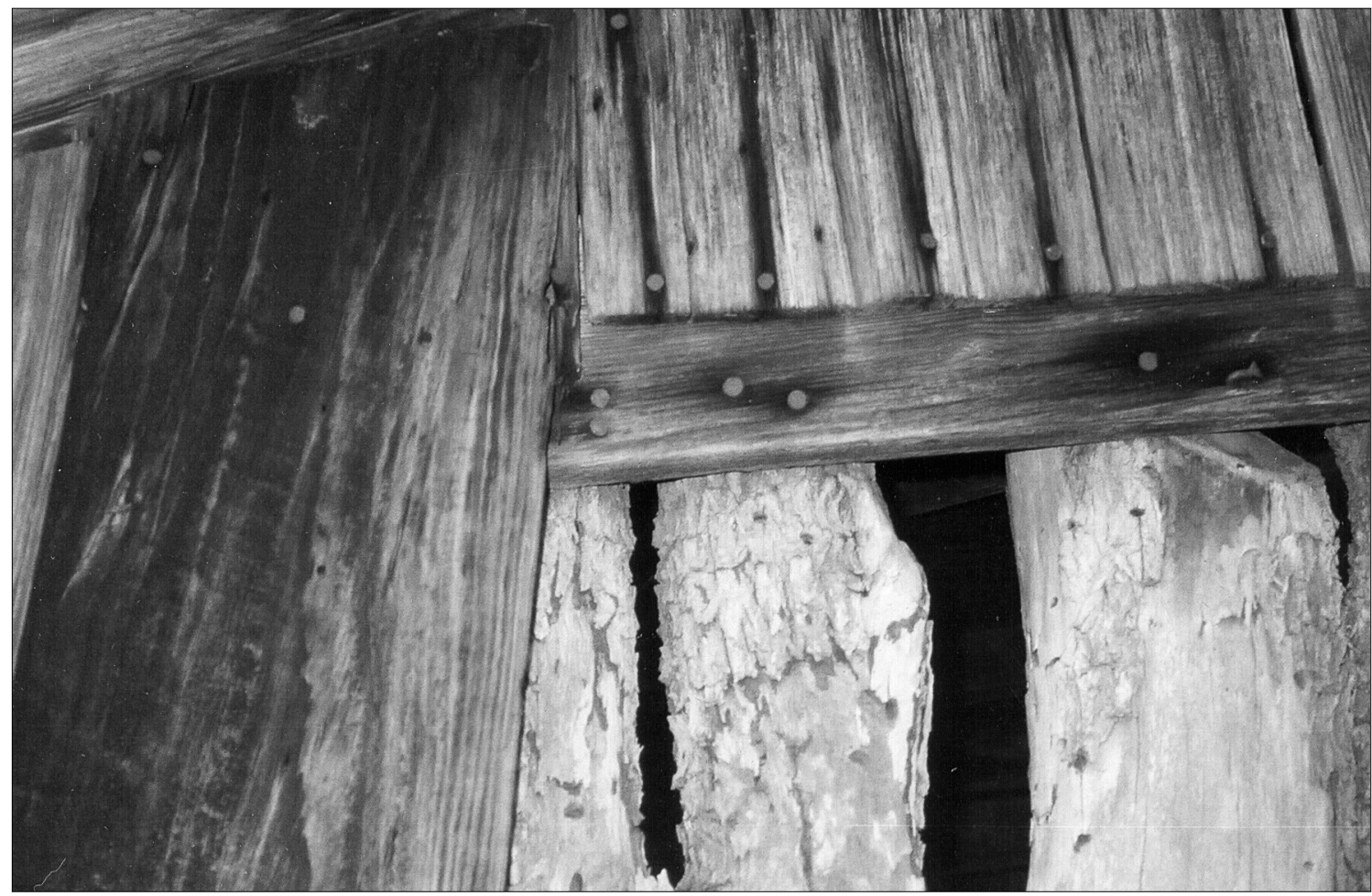

Figure 9. Construction detail of goat herder's shack at site 41BX274.

diagnostic (see Figure 10c). The ears of the pot are formed by a horizontal piece coming from the neck/rim and a vertical piece from the shoulder. This forms a sharply angled ear as shown in Figures 10a and 10b, but by 1830-1840, the ears of such kettles were made from one piece and rounded (Figure 10c; The Engagé 1997:4; Tyler 1978:31). This places the kettle's age at around 1840 or 1850 , closely following the arrival of the Perez family at the beginning of the nineteenth century. Concentration $\mathrm{C}$ is near the area where remains of a jacal structure were postulated to be during earlier investigations (McGraw and Hindes 1987: 114-115). This structure would have been 60 meters west/ northwest of the main ranch house.

Following the surface survey, Backhoe Trenches (BHTs) 1, 2 and 3 were placed along the eastern edge of the site. This was done to aid in definition of the site boundary in the ranch area and explore the possibility of deeply buried prehistoric components. All three backhoe trenches were in the fallow agricultural field and evidenced a clear plow zone disturbance (see Appendix A). Recovered from the plow zone of BHT 1, near Concentration A, were fragments of animal bone, one piece of lithic debitage, two historic glass fragments, one sherd of late-nineteenth-century handpainted ware and one sherd of early-nineteenth century (Spanish Colonial) Mexican utilitarian ceramic. All artifacts were less than $50 \mathrm{~cm}$ below surface $(\mathrm{cmbs})$ and well mixed in the plow zone. BHT 2 and BHT 3 failed to recover any cultural material and are considered outside of the site boundaries.

The borders of the Perez Ranch Section of 41BX274 are identified by Boundary Markers 3, 4, 5, 16, and 17 and the UTM coordinates are listed in Table 2 (this table included in pocket at back of report). Boundary Marker (BM) 3 is set in the open pasture along the fence approximately 100 meters north of a large mesquite tree. BM 4 is located at the southern end of BHT 2 in the open pasture while BM 5 is located along a fence line 10 meters west of the irrigation pipe running across the pasture. BM 16 is set in dense brush at the edge of the high terrace approximately 20 meters south of the east-west road cut heading down the terrace. BM 17 is in a dense brushy location along the edge of the high terrace and marks the northwest corner of the site. 


\section{The Prehistoric Component of 41BX274}

Surface survey to the north of the ranch section identified two prehistoric lithic scatters, Concentrations D and E (Figure 2). Investigations conducted in 1987 in this northern portion of the site identified buried burned rock features and diagnostic artifacts including an Early Triangular biface/ point, a Guadalupe biface, and Bell and Martindale dart points (McGraw and Hindes 1987:117-121).

Concentrations F, G, H, and J are located at the southern portion of site 41BX274. These concentrations consist of prehistoric scatters of lithics and FCR.
During the current survey, Concentrations $\mathrm{F}$ and $\mathrm{J}$ (Figure 2) contained light to moderate lithic scatters of debitage, worked flakes and FCR exposed in the ranch road. Visibility was 80 to 100 percent in the two-track road, gradually decreasing away from the road as the vegetation increased. Concentrations $\mathrm{F}$ and $\mathrm{J}$ are separated by roughly 70 meters of grassy road where the visibility dropped to between 5 and 25 percent. To investigate the subsurface deposits in Concentration F, one backhoe trench, BHT 8, was excavated. No cultural materials were noted in the trench despite the fact that debitage and a unifacially worked flake were present on the surface less than 3 meters away.

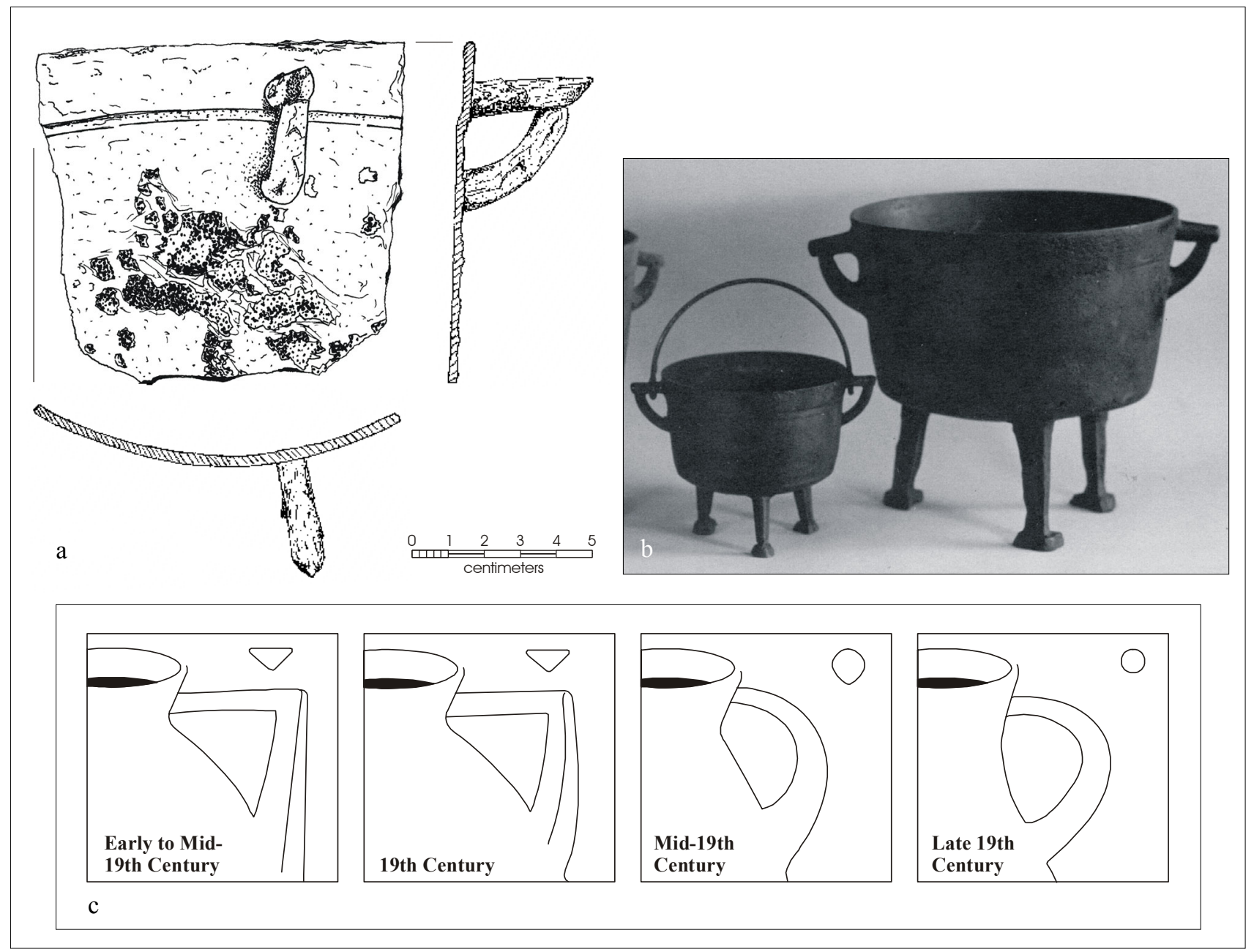

Figure 10. Identification of the iron kettle fragment recovered from 41BX274, Concentration C. a) Illustration of kettle fragment; b) Photograph of iron tripod kettles (adapted from The Engagé 1997: Figure 1); c) Illustration of kettle stylistic changes (adapted from Tyler 1978:Figure 12). 
Concentration $\mathrm{G}$ is north of the road cut and contains a moderate scatter of debitage, cores, and FCR. Surface visibility ranged between 50 and 100 percent. Owing to the extent of the scatter and the presence of surface material beyond the original site boundary, 31 shovel tests and three backhoe trenches (BHTs 4, 5, and 6) were placed within and in the general vicinity of this concentration (Figure 11, located at back of report). Of the 31 shovel tests, eight (26\%) were positive yielding one to two pieces of lithic debitage per shovel test distributed between 0-40 cmbs. Two flakes were identified in the southeast wall of BHT 4 at approximately $45 \mathrm{cmbs}$ (Appendix A). BHT 5 and BHT 6 both failed to recover any cultural material.

Concentration $\mathrm{H}$, located south and west of Concentrations $\mathrm{F}$ and $\mathrm{G}$, is along the heavily eroded edge of the high terrace (Figures 2 and 11). Surface visibility was between 90 and 100 percent, decreasing away from the bluff edge as the vegetation became denser and the erosion was less significant. The surface scatter consists of light to moderate densities of debitage and FCR. Collected from Concentration $\mathrm{H}$ was a rough, bifacially worked scraper. BHT 9, along with a transect of nine shovel tests, was placed in the area between Concentrations $\mathrm{F}$ and $\mathrm{H}$ to test for buried cultural materials. The results of all backhoe trenching and shovel testing between the concentrations were negative. Despite the lack of buried deposits, a very light deposit of cultural deposits does exist between these two concentrations.

Due to the lack of surface materials in the portion of the site southeast of Concentrations F, G and $\mathrm{H}$ and west of Concentration I, 39 shovel tests were placed in transects throughout this section of the site (Figure 11). All shovel tests were spaced at 30-meter intervals. One transect was placed along the northern edge of the site. A second transect ran through the central portion of the site and looped back on itself to follow the bluff edge. Additional shovel tests were then added to assure thorough coverage. None of the 39 shovel tests recovered cultural material between Concentrations $\mathrm{G}$ and $\mathrm{H}$ and Concentration I. This is not surprising, since the original CAR investigation of this area describe it as having a "paucity" of artifacts (McGraw and Hindes 1987:118).

With the exception of Concentration I, it appears that there are no artifact deposits present in the 15.7-acre southeastern one-third of site 41BX274. The area devoid of cultural materials is bounded by BMs 9 to 11 and BMs 13 to $14 \mathrm{~b}$ (see dashed line in Figure 11; Table 2). This void separates Concentrations $\mathrm{G}$ and $\mathrm{H}$ from Concentration I by 350 meters.
Concentration I is well isolated from all other concentrations associated with 41BX274, therefore, it has been defined as a new site, 41BX274a. With the removal of the area devoid of cultural materials and the separation of Concentration I as a separate site (41BX274a), the new limits of 41BX274 are BM numbers 1, 2, 3, 4, 5, 6, 7, 8, 9, 14b, 15, 16, and 17 (Figures 2 and 11). This area totals 28.27 acres.

\section{$41 \mathrm{BX} 274 \mathrm{a}$}

41BX274a consists of Concentration I and is marked by BMs 11,12 and 13 (Figure 11). The size of this site is 2.81 acres. 41BX274a was once part of 41BX274 and sits just west of Applewhite Road (Figures 2 and 11). This site is a light scatter of prehistoric debitage and a moderate scatter of historic glass and metal dating from the mid- to latenineteenth century (Figure 8, n-o). Following the surface survey, four shovel tests were placed on the site. Bedrock outcrops are visible in the area and one shovel test reached the sandstone bedrock at $38 \mathrm{cmbs}$. Two shovel tests yielded one flake each, both from Level $1(0-10 \mathrm{cmbs})$. The remaining two shovel tests were void of cultural materials. In 1987, two backhoe trenches in this area yielded very few debitage and some mussel shell fragments. No features or diagnostic artifacts were encountered (McGraw and Hindes 1987:117, 123). The relationship between the historic materials at the Perez Ranch is uncertain but the age of the historic materials do coincide with the latter occupation of the Perez Ranch at site 41BX274. The relationship between 41BX274a and 41BX661, an early-twentieth-century tenant farmer's shack located directly across Applewhite Road (Figure 2) is unknown, but owing to the proximity, an association does seem possible. It should be noted that 41BX661 is outside this project area and not of direct concern.

\section{Summary of 41BX274 and 41BX274a}

Site $41 \mathrm{BX} 274$ is a multicomponent site containing the remains of the Perez Ranch Complex and a large prehistoric lithic scatter. Testing in 1987 and the reassessment conducted during this project revealed several areas of low to moderate lithic surface scatters (Concentrations A, D, E, F, G, H, and $\mathrm{J})$ and significant buried deposits to the north around Concentrations D and E. Previous recovery of diagnostic artifacts from 41BX274 includes Guadalupe bifaces, Clear Fork tools, and Bell dart points (McGraw and Hindes 1987:109, 118, 121) dating to the Early Archaic (Turner and Hester 1999:80, 246, 256). Also recovered were Marshall and Martindale dart points (McGraw and Hindes 1987:109, 121) from the Middle Archaic (Turner and Hester 
1999:149), a Perdiz arrow point (Late Prehistoric), and Goliad ware ceramics from the Late Prehistoric to the early Historic period (McGraw and Hindes 1987:109). The prehistoric component represents camp locations indicated by burned rock features and chert procurement/tool manufacture locations as inferred by the presence of debitage, tools and cores made from river-rounded chert available from gravel bars in the Medina River.

The historic component is represented by the Perez Ranch located in the northern one-third of the site. The ceramics, glass, and iron artifacts date the site from to the early nineteenth century through the late nineteenth century, a nearly 100-year span of time. Archival research and test excavations performed by CAR in the 1980s provided much information of the history of the Perez Ranch. Records document the increase and decrease in the Perez family landholdings throughout the 1800 s as well as Juan Ignacio Perez's rise to prominence in San Antonio de Bexar (McGraw and Hindes 1987:110-113). The 1987 investigations identified the main ranch house site and numerous outbuildings indicative of a ranching or farming operation.

Geoarchaeological investigations associated with the backhoe trenches recovered artifacts from only two trenches (BHTs 1 and 4) out of the nine trenches excavated, and concluded that the opportunity for deeply buried cultural deposits was low (see Appendix A).

Surface survey and shovel testing in the southernmost onethird of the site identified no cultural materials except at Concentration I near Applewhite Road. As no cultural material was identified in the area of the site between the artifact concentrations in the north $(\mathrm{A}-\mathrm{J})$ and Concentration I, the 15.7 acres of land between these two areas has been removed from the site boundaries and Concentration I was defined as a separate site, 41BX274a.

Backhoe trenching in 1987 and shovel testing during the current project has shown 41BX274a to be a multicomponent site, separate from 41BX274. This site has a prehistoric lithic scatter of an undetermined age in a highly eroded, low-density, shallow deposit. The historic component is mid- to late-nineteenth-century in origin and is on the surface or very shallowly buried. The density is moderate. The historic artifacts may or may not bear some relationship to the Perez Ranch (41BX274) more than 350 meters distant or to the tenant farmers shack (41BX661) across the road from 41BX274a.

\section{Site 41BX277: The Perez Family Cemetery and Chapel}

Originally, this site was defined as a single component historic cemetery. Reassessment and boundary definition of the historic Perez Family Cemetery and Chapel began with a 100 percent pedestrian surface survey inside the cemetery fence and extending 20 meters beyond that barrier. Surface visibility ranged from 60 to 100 percent.

The most visible feature of the site is the grave markers and small chapel protected by an ordinary livestock fence. Graves are identifiable by markers of metal, wood and stone. A total of 41 markers is present but some graves are double marked. Many of the original wood and rough sandstone markers are broken or rotten and have been replaced by galvanized steel and tin, crucifix-shaped markers that stand beside the original markers. Most burials lie to the west of the chapel with additional interments located inside the chapel. A livestock fence erected around the chapel and cemetery defines the boundary of the historic component (Figure 3).

A light debitage scatter was noted in the road cut outside the fence. Three shovel tests were excavated along the road to investigate the depth of this lithic scatter. Two shovel tests were negative and one yielded a single chert flake from Level $1(0-10 \mathrm{cmbs})$. This artifact was noted but not collected. It was recovered well within the disturbed context of the plow zone. While debitage was present in the road cut just two meters from the cemetery fence, no debitage was noted inside the fence, despite the surface visibility being 70 to 90 percent. Based on the presence of this scatter, the boundary of 41BX277 has been enlarged beyond the cemetery fence (see Figures 2 and 3).

The historic component at this site dates from the early nineteenth century with the earliest documented interment being that of Juan Ignacio Perez in 1823 placed inside the family chapel at the center of the cemetery (McGraw and Hindes 1987:110). Examination of grave markers shows the most recent identifiable burials to be Manuel Espinoza in 1932 and Emilia Z. Garibay in 1936. Given the light scatter of non-diagnostic lithics, the prehistoric component cannot be dated.

The prehistoric scatter is visible in the area around the ranch road south and east of the cemetery fence (see dashed line in Figure 3) delimited by BMs 1, 2, 3, and 4 . The entire site 
boundaries are marked by BMs 1, 2, 3, 5, 6 and 7 (Table 2). The new total acreage for 41BX277 is 2.03 acres. Given the presence of both prehistoric and historic materials at this location, it is recommended that the site should be designated as representing a multicomponent rather than single-component archaeological property.

\section{Site 41BX682: The Dolores Crossing}

The Dolores Crossing was the primary ford across the Medina River for the Perez Ranch and may have been fortified by rebels during the Battle of Medina. It consisted of no structure, but only the natural shallow waters over a solid, even gravel bar (McGraw and Hindes 1987:260). This ford was likely the crossing for the Camino Real headed south for the Rio Grande (Camino Real para el Rio Grande) and still functions as a crossing of the Medina River via a one-lane concrete bridge on Applewhite Road. A 100 percent pedestrian surface survey identified no cultural material other than the bridge. No shovel testing or backhoe trenching was performed at this site.

To mark the site, four stakes have been set into the ground forming a circle 50 meters in radius. Each stake is 50 meters from the center of the bridge (Figure 6). The north boundary marker is 50 meters north along the current course of Applewhite Road while the south boundary marker is 50 meters south along the current road. The west boundary marker is 50 meters from the bridge center and can be found in the woods down a trail on the north bank of the Medina River. The east boundary marker is 50 meters into the woods along a trail on the south bank of the Medina River. The UTM coordinates for the boundary markers are provided in Table 2. The total area of this site is 2.77 acres. Of this total, only 0.69 acres falls within the boundaries of the current project area, that portion of the site west of Applewhite road and north of the Medina River.

\section{Site 41BX988: The Laborer's Shack}

This site was the location of a small tenant farmer's/laborer's shack in the early twentieth century that burned in the 1940s. The site is the only archaeological site in the project area associated with the workings of the Perez Ranch in the twentieth century. A 100 percent surface survey was conducted and eight shovel tests were excavated to define the site boundaries.

Surface survey noted a moderate scatter of primarily earlytwentieth-century artifacts, although a single Colonial tinglazed ceramic was also recovered (Figure 8, p-r). The majority of the artifacts consisted of glass from windows, jars and a glass marble, ceramic sherds from plates and cups, wire cut nails, and animal bone. Eight shovel tests were placed within the original, larger site bounds (Figure 7). Five shovel tests yielded historic artifacts and were all well inside the current surface scatter. The materials were concentrated in Levels 1-4 (Table 3). Based on the surface scatter and the results of shovel testing, the site is defined as 60 meters north-south by 35 meters east-west. This totals 0.40 of an acre. Four boundary markers (BMs 1-4) were established, delineating the extent of the site (Table 2).

The site was judged to be only 15 percent intact at the time of its original recording. Its current condition is at best 10 percent intact. Given the heavy plow-inflicted disturbances to these historic deposits, the materials have been heavily reduced and their vertical and horizontal associational integrity has been reduced. The site appears to retain low research potential.

Table 3. Distribution of Cultural Materials from Shovel Tests at 41BX988

\begin{tabular}{|c|l|l|l|l|}
\hline Level & \multicolumn{1}{|c|}{ ST 2 } & ST 3 & ST 4 & \multicolumn{1}{c|}{ ST 7 } \\
\hline $1(0-10 \mathrm{cmbs})$ & 1 clear glass; 1 white earthenware & & & \\
\hline $2(10-20 \mathrm{cmbs})$ & & & & 1 white earthenware \\
\hline $3(20-30 \mathrm{cmbs})$ & 1 clear glass & & & 1 tack \\
\hline $4(30-40 \mathrm{cmbs})$ & 1 white earthenware & 1 wire nail & 1 clear glass & \\
\hline
\end{tabular}




\section{Summary and Recommendations}

\section{Summary}

Staff of the Center for Archaeological Research conducted pedestrian survey and subsurface investigations to establish the current site boundaries of four archaeological sites, 41BX682, 41BX274, 41BX277, and 41BX988 located west of Applewhite Road in south-central Bexar County. The process of establishing the site boundaries for 41BX274 resulted in the division of it into two separate sites, 41BX274 and 41BX274a. The initial four sites were originally recorded in the early 1980s during CAR surveys of the former Applewhite Reservoir project. As part of the final deliverable for the project, CAR has staked the boundaries of all five sites and provided the global positioning coordinates of these boundary markers to the client.

The redefinition of site boundaries for 41BX274 included a 100 percent pedestrian survey complemented by shovel testing and backhoe trenching. The results of the fieldwork confirm that 41BX274 is a multicomponent site, but reduced it in size by eliminating an area devoid of artifacts and separating an isolated artifact concentration (Concentration I) into a new site, 41BX274a. The survey of 41BX274 identified several artifact concentrations. Subsurface testing using both shovel tests and backhoe trenches identified only shallowly buried cultural deposits across the site. Concentrations A, B, and C contain the historic component present at the site. Concentrations D, E, F, G and H contain low-density prehistoric materials consisting primarily of chipped lithic debitage and fire-cracked rocks. These concentrations of cultural materials are connected by sparse, widely scattered cultural debris.

41BX274a (formerly Concentration I) is southeast of 41BX274 and separated by approximately 350 meters from the nearest artifact concentrations (Concentrations $\mathrm{G}$ and $\mathrm{H}$ ) at 41BX274. The intervening area is devoid of surface and subsurface cultural materials. 41BX274a contains both surface and shallowly buried prehistoric and historic materials.

Results of the surface survey and shovel testing confirmed the existence of the historic component at 41BX277, the Perez Family Cemetery and Chapel, and identified a sparse prehistoric component immediately outside of the boundaries of the cemetery.
The relocation of the Dolores Crossing (41BX682) was easily accomplished because it is located at the modern crossing of the Medina River by Applewhite Road. Four boundary markers were positioned at cardinal directions centered on the bridge over the river. No cultural materials were identified during the site revisit.

The survey and shovel testing of 41BX988 identified a small 60 by 35 meter concentration of historic materials. The materials have been heavily reduced in size and reflect the results of repeated plowing of the open field. The materials retain low vertical and horizontal associational integrity.

\section{Recommendations}

The primary goal of the archaeological work at the four sites has been to re-establish site boundaries. While in some instances (41BX682) this could be accomplished simply by pedestrian survey, in the case of three sites, 41BX274, 41BX277, and 41BX988, subsurface investigations were also necessary. The recommendations derived from this work address new findings and how these implicate the spatial limits and temporal definitions of the sites rather than their National Register of Historic Places and/or State Archeological Landmark eligibility. None of the work conducted by CAR was strictly directed to determine the NRHP and SAL eligibility of these properties, although it is clear that the results have such implications.

In the case of 41BX274, the original site size is reduced by approximately 15.7 acres. The present site boundaries, as defined based on the current fieldwork, are limited to the northern half of the former site. The multicomponent site includes artifact concentrations $\mathrm{A}-\mathrm{H}$ and $\mathrm{J}$ and is delineated by Boundary Markers 1, 2, 3, 4, 5, 6, 7, 8, 9, 14b, 15, 16, and 17 . This new site area constitutes 28.27 acres.

41BX274a is a concentration of historic and prehistoric materials, located 350 meters from the nearest concentration on 41BX274 and has thus been defined as a separate multicomponent site consisting of 2.81 acres. The remaining 12.89 acres removed from the original boundaries of 41BX274, and that lay between it and 41BX274a, are no longer considered part of any archaeological site. 
Site 41BX277 was originally defined as the historic Perez Family Cemetery. The current fieldwork revealed a sparse surface scatter of lithic debitage in the vicinity of the cemetery. Based on this finding, it is recommended that the site be defined as multicomponent. The entire site boundaries should be defined as the area contained within and marked by Boundary Markers 1, 2, 3, 5, 6 and 7 .

Site 41BX682 is the historic Dolores Crossing of the Medina River. Although no artifacts or physical indicators of the historic crossing exist, previous research has established this as the location of the crossing (McGraw and Hindes 1987:260). Four boundary markers (1-4) forming a circle 50 meters in radius and centered on the Applewhite Road bridge spanning the Medina River identify the location and extent of the site.

Finally, site 41BX988 is the location of a laborer's shack that may have burned down during the 1940s. Based on surface inspection and shovel testing, the site boundaries have been redefined to include an area measuring approximately 60 by 35 meters and delineated by Boundary Markers 1-4. This site size is smaller than that defined during the original recording of the site. 


\section{References Cited}

Cestaro, G. C., M. D. Freeman, M. E. Blake, and A. M. Scott

2001 Cultural Resources Survey of Selected Maneuver Areas at Camp Bullis, Bexar and Comal Counties Texas: The Archaeology and History of 3,255 Acres Along Cibolo Creek. Reports of Investigations No. 129. Prewitt and Associates, Inc., Austin, Texas and the U.S. Army Corps of Engineers, Fort Worth District.

Chapa, J. B., and W. C. Foster (editor)

1997 Texas and Northeastern Mexico, 1630-1690. Translated by N. F. Brierley. University of Texas Press, Austin.

Collins, M. B.

1995 Forty Years of Archeology in Central Texas. Bulletin of Texas Archeological Society 66:361-400.

Cox, I. W.

1997 Chapter 2: The Growth of San Antonio. In Archaeology at the Alamodome: Investigations of a San Antonio Neighborhood in Transition, Volume I, Historical, Architectural, and Oral History Research edited by A. A. Fox, M. Renner, and R. J. Hard, pp. 8-44. Archaeological Survey Report, No. 236. Center for Archaeological Research, The University of Texas at San Antonio.

Decker, S. S. L. Black, and T. Gustavson

2000 The Woodrow Heard Site, 41UV88, A Holocene Terrace Site in the Western Balcones Canyonlands of Southwestern Texas. Studies in Archaeology 33, Texas Archeological Research Laboratory, The University of Texas at Austin and Archaeology Studies Program Report 14, Environmental Affairs Division, Texas Department of Transportation, Austin.

Engagé, The

1997 French Marmites. The Museum of the Fur Trade Quarterly 33(4):4. The Museum of the Fur Trade, Chadron NE.

Figueroa, A. L., and S. A. Tomka

2004 Archaeological Survey of the Proposed Medina River Park, Bexar County, Texas. Archaeological Survey Report, No. 345. Center for Archaeological Research, The University of Texas at San Antonio.

Henson, M. S.

1996 Lorenzo de Zavala: The Pragmatic Idealist. Texas Christian University Press. Fort Worth.

Johnson, L., and G. T. Goode

1994 A New Try at Dating and Characterizing Holocene Climates as well as Archeological Periods on the Eastern Edwards Plateau. Bulletin of Texas Archeological Society 65:1-54.

Mauldin, R. P., and D. L. Nickels

2001 An Archaeological Survey of Twin Buttes Reservoir, Tom Green County Texas, Volume 1. Archaeological Survey Report, No. 300, 3 volumes. Center for Archaeological Research, The University of Texas at San Antonio.

Mauldin, R .P., D. L. Nickels, and C. J. Broehm

2003 Archaeological Testing to Determine the National Register Eligibility Status of 18 Prehistoric Sites on Camp Bowie, Texas, Volume 1. Archaeological Survey Report, No. 334, 2 volumes. Center for Archaeological Research, The University of Texas at San Antonio. 
McGraw, A. J., and K. Hindes

1987 Chipped Stone and Adobe: A Cultural Resource Assessment of the Proposed Applewhite Reservoir, Bexar County, Texas. Archaeological Survey Report, No. 163. Center for Archaeological Research, The University of Texas at San Antonio.

Turner, E. S., and T. R. Hester

1999 A Field Guide to Stone Artifacts of Texas Indians. Third edition. Gulf Publishing, Houston.

Tyler, J. D.

$197818^{\text {th }}$ and $19^{\text {th }}$ Century Cast-Iron Cooking Utensils. Early American Life 9(2):30-31. The Early American Society, Gettysburg PA. 
The Perez Ranch Project

\title{
Appendix A: Geoarchaeological Investigations of the Perez Ranch Section of 41BX274
}

\author{
by Russell D. Greaves
}

A total of nine backhoe trenches was excavated to examine the potential for buried archaeological deposits and characterize the geoarchaeological setting of 41BX274. The locations of the trenches are provided in Figure 2 of the main report. All trenches were at least $6 \mathrm{~m}$ long and the target elevation for their maximum depth was approximately $1.5 \mathrm{~m}$ below the modern ground surface. Trenches were one backhoe bucket width, approximately $50 \mathrm{~cm}$. One wall of each backhoe trench was profiled and drawn. Both walls were troweled and examined for evidence of any potential archaeological materials or significant indicators of formation events. Full soil descriptions were performed on five of the profiles. Soils and sediments in the other trenches were sufficiently similar that additional descriptions were unnecessary. The trenches were located in several different settings that suggest the identified prehistoric components are recent deposits present in the upper portions of the profiles. Complete field soil observations included soil texture, consistence (wet only), presence and morphology of clay films, grain coatings, structure, abundance and size of roots, abundance and size of pores, horizon boundaries, and Munsell colors (wet only). These attributes permit designation of the soil and sedimentary horizons in standard soil nomenclature (Birkeland 1984:353-360; Soil Survey Staff 1993:117-135).

The majority of the soils in the project area are identified as Hockley loamy fine sand on 0-3 percent slopes (Taylor et al. 1962:17-18). These soils have served as cultivated lands in much of Bexar County. The younger soils in the ephemeral drainage settings where BHTs 6 and 7 were located resemble the Venus clay loam (Taylor et al. 1962:32-33) that is mapped adjacent to the scarp of the high terrace. Clasts (gravels, pebbles, caliche, etc.) were uncommon in all trenches. No charcoal samples were collected for chronometric dating. All of the upper solum is considered to be Holocene. The Bt soils in BHTs 1, 2, and 3 may be of Late Pleistocene age. The Bk soils in BHTs 4, 5, 8, and 9 are likely Holocene.

BHTs 1, 2, and 3 were situated in a currently fallow agricultural field (now a pasture setting) that represents the highest and oldest terrace examined in this investigation. Younger soils are present in an eastward progression; however, previous investigations have not identified archaeological sites in the eastern portion of this field. They could be deeply buried, disturbed by channel meander events, or they may be absent from that portion of the high terrace of the Medina River.

BHTs $4,5,6,7,8$, and 9 were placed on a lower terrace unit than the position of BHTs 1, 2, and 3. BHTs 4-9 were all on an essentially equivalent terrace surface. BHTs 4,5 , and 6 were excavated to determine if near surface or buried archaeological remains could be identified outside of the current inferred boundary of the prehistoric deposits of 41BX274. There are elevational differences and more open vegetation than the area just northwest of the location of BHTs 4 and 5. This area was selected because surface survey and shovel testing at Concentration $\mathrm{G}$ identified surficial prehistoric lithics. BHT 6 also examined this area that contains significant amounts of surface artifacts, but was located on what appears to be a younger surface associated with recent drainage deposits closer to the eroded bank margin of the abandoned terrace of the Medina River.

BHTs 7, 8 and 9 represent a sequence of trenches excavated to determine whether the relatively discrete distributions identified through surface artifacts (Concentrations $\mathrm{F}$ and $\mathrm{H})$ and shovel testing were associated with other buried remains. These trenches were on the same terrace as BHTs 4,5 , and 6 , but were much closer to the eroded southern margin of that feature (Figure 2, main report). They were excavated from the northwest to southeast along comparable areas between the nineteenth-century remains of the Perez Ranch structure and two areas with significant amounts of surface and epipedon deposits exposed in areas of erosion. BHT 7 was southeast of the historic ranch structure near the terrace margin. BHTs 8 and 9 were situated between exposures of archaeological material in the roadway and southern margin of the abandoned high terrace of the Medina River farther southeast from the ranch location.

\section{BHT 1}

BHT 1 was excavated $10.6 \mathrm{~m}$ long and it was oriented $94^{\circ}-$ $264^{\circ}$ from magnetic north. The trench was maximally 144 $\mathrm{cm}$ deep. BHT 1 was located near the remains of the ranch structure that contains nineteenth-century artifacts, on the same terrace surface as the identified remains. This was the only backhoe trench to contain significant amounts of cultural artifacts. The northern wall of the trench was drawn 
and described. The profile consists of a recent plow zone (Ap horizon) underlain by six $\mathrm{Bw}$ horizons that show significant rubification (Figure A-1, Table A-1).

All artifacts were found within a disturbed plow zone (Ap) horizon. A total of six historic artifacts was found in the profile. These include one ceramic sherd that is probably Colonial period, two ceramic sherds that are late-nineteenthcentury, one piece of green bottle glass, and a small cupric metal artifact. Additionally, three pieces of burned bone, and three pieces of unburned bone were recovered in the plow zone. The condition of the unburned bone indicates it is recent, and the burned bone is most likely associated with the historic materials. One of the unburned bones is a long bone fragment exhibiting a fresh bone break. Obviously recent charcoal also was observed in several portions of the plow zone. A single prehistoric flake was found at the base of the plow zone at the contact with the older underlying Bw1 soil. This item was within the disturbed epipedon and was not in the intact older soil of the profile of BHT 1. All of these materials were located within the plow zone that is expressed from $0 \mathrm{~cm}$ to approximately $36 \mathrm{~cm}$ below the current ground surface in this trench. All of these items were identified in the lower 10-20 cm of the Ap unit. BHTs 2 and 3 were located in slightly lower settings on a series of progressively younger terraces within the same landform.

At the base of the Ap horizon, the contact with the underlying Bw1 soil is an unconformity. Displaced peds of the Bw1 are present within the Ap unit. There is no intact A horizon or other genetically related soils associated with the recent plow zone. All of the soils below the modern Ap represent older Bw horizon soils (Bw1-Bw6). Although all of these soils are calcareous, there were no filament or nodule structures visible in any portion of these deposits and no areas of visible whitening. The B horizon soils are similar to those seen in BHT 2 and BHT 3 . The difference between the trenches is that there were thicker recent sediments and intact portions of the A horizon below the plow zone in BHTs 2 and 3.

\section{BHT 2}

BHT 2 was located east of BHT 1 and was directly downslope from the scatter of surface materials that identify the location of the ruins of the nineteenth-century structure. This trench was in a very slightly lower topographic position. The presence of a thicker A horizon than in BHT 1 indicates that this location has received a greater amount of recent sedimentation and the epipedon is younger than in BHT 1. The length of BHT 2 was $9.8 \mathrm{~m}$ and it was excavated to a maximum depth of $134 \mathrm{~cm}$. The trench was oriented $89^{\circ}-$ $269^{\circ}$ from magnetic north. The southern wall of BHT 2 was profiled. Soils were almost identical to BHT 1 and no detailed soil descriptions were recorded for this trench. BHT 2 contained a plow zone Ap horizon underlain by an A1 horizon that has an unconformity with the underlying Bw1 horizon. A total of five $\mathrm{Bw}$ soils was distinguished below the A horizons (Figure A-2).

No cultural artifacts were identified in BHT 2. Two pieces of bone were collected from the Ap horizon. These do not offer any unambiguous evidence of being butchered and appear to be recent bone fragments that could represent natural death inclusions. [Supportive of this, surface survey noted numerous scatters of cattle bones throughout the project area of a type common to cattle ranches. The natural bovine deaths are estimated have been within the past 1 to 5 years.] The contact between the A1 and the Bw1 unit is abrupt and appears to represent an erosional unconformity. The Bw horizons are rubified, but also show evidence of gleying. Both the $\mathrm{Bw} 1$ and $\mathrm{Bw} 2$ are noticeably oxidized but also contain evidence of gleying. Bw3 and Bw4 are more reduced, had greater visible gleying, and were reddened only from localized ferric mottling. There are manganese nodules formed in the $\mathrm{Bw} 2-\mathrm{Bw} 4$ horizons. Bw5 is more oxidized than the overlying $\mathrm{Bw} 3$ and $\mathrm{Bw} 4$ units. The evidence of gleying appears to be due to irrigation of this field and the water retention qualities of the $\mathrm{Bw}$ units (Taylor et al. 1962:18).

\section{BHT 3}

BHT 3 was placed southeast of BHT 2 and represents the lowest setting in the group of three trenches in the agricultural field adjacent to the nineteenth-century ranch structure remains. BHT 3 was $9.6 \mathrm{~m}$ long and maximally $130 \mathrm{~cm}$ deep and was oriented $97^{\circ}-277^{\circ}$ from magnetic north. The southern wall of this trench was drawn (Figure A-3) and the soils described (Table A-2). This trench contained no evidence of any archaeological material. It did show differences in the stratigraphy that indicate the alluvial history of these deposits. At the eastern end of BHT 3, the lower Bw horizons dip significantly and there is an associated overthickening of the A horizons in this part of the trench. Like BHT 2, the western two-thirds of BHT 3 has a single A1 horizon that underlies the plow zone Ap unit. The A horizon (including the Ap) is approximately $35-$ $45 \mathrm{~cm}$ deep in the western portion of the profile. At the eastern end of BHT 3, the A horizon is $89 \mathrm{~cm}$ deep and extends deeper below the portion excavated by the backhoe. There are three intact A horizons (A1-A3) underlying the 

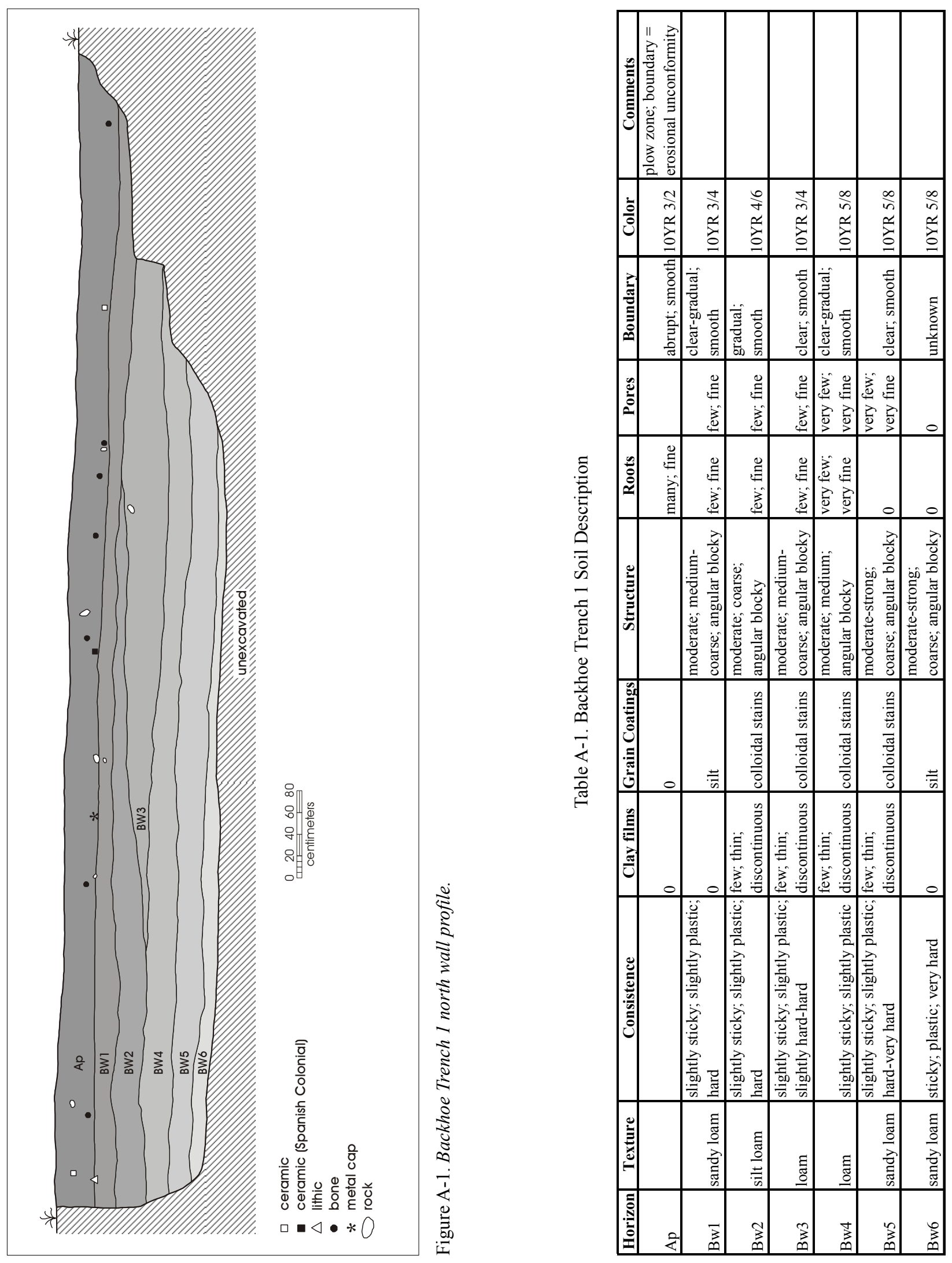


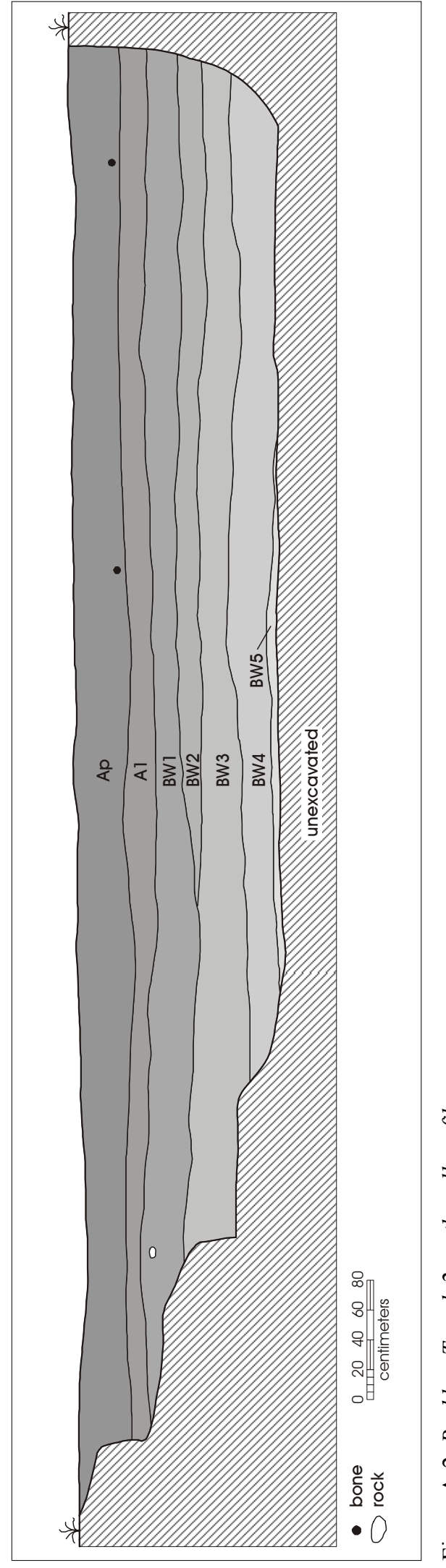

Ap in this portion of the trench. Because none of the A1A3 units appear to be disturbed, it does not appear that this represents an older irrigation channel. This is evidence of a previous channel cut into the sediments now identified as the Bw soils. A shallow dip in the upper boundary of the Bw1 and A1 horizons in the western end of the trench (approximately 1-1.8 m east of the western end of the trench) may be a shallow drainage cut associated with the evidence for a larger channel at the eastern end of the trench. The A1 unit has no evidence of any cultural or erosional interruptions that would suggest recent agricultural activities. The Ap contains abundant evidence of mixed sediments and large pieces of modern charcoal.

A series of channel meanders are visible east of all the locations of BHTs 1, 2, and 3 in aerial photographs of the project area. Trenching experience on the Toyota plant property (The Starbright Project; see Previous Investigations Section of main report) northeast of the current project area indicate that such visible meanders are likely to be very deeply buried below the modern ground surface. The fortuitous encounter with a channel cut and fill episode at the eastern end of BHT 3 strongly assists the interpretation that this series of backhoe trenches (BHTs 1, 2, and 3) vary only in their relative age and pedogenic events due to their positions on a series of very gradually changing floodplain locations.

\section{BHT 4}

BHT 4 was $8.62 \mathrm{~m}$ long and oriented $46^{\circ}-226^{\circ}$ from magnetic north. The trench was maximally $140 \mathrm{~cm}$ deep. The northwestern wall was drawn (Figure A-4) and the soils fully described (Table A-3). The soils in BHT 4 represent a group of three A horizons overlying two B horizons (B1 and $\mathrm{B} 2$ ) that rest on what appears to be an older sequence of Bk soils (Bk1-Bk2). There are few fine filaments of calcium carbonate in the $\mathrm{B} 2$ horizon. There is a dramatic increase in calcium carbonate in the two lower Bk horizons. Carbonate nodules are abundant in both $\mathrm{Bk}$ horizons and increase in size between the Bk1 unit $(<2 \mathrm{~cm})$ and the $\mathrm{Bk} 2$ $(<4 \mathrm{~cm})$ unit. Both $\mathrm{Bk}$ horizons show significantly greater amounts of $\mathrm{CaCO}_{3}$ than in the overlying $\mathrm{B} 1$ and $\mathrm{B} 2$ units and strongly indicate the presence of an older soil sequence capped by the modern A1-A3 and B1-B1 solum. The soils in BHT 4 are very similar to those in BHT 5.

Two lithics were recovered from the southeastern profile wall of BHT 4. Both flakes were found at the base of the A3 or top of the B2 horizons within $1 \mathrm{~cm}$ horizontally of each other. One is a proximal fragment of an almost complete flake and the other is a distal margin. No other evidence of 

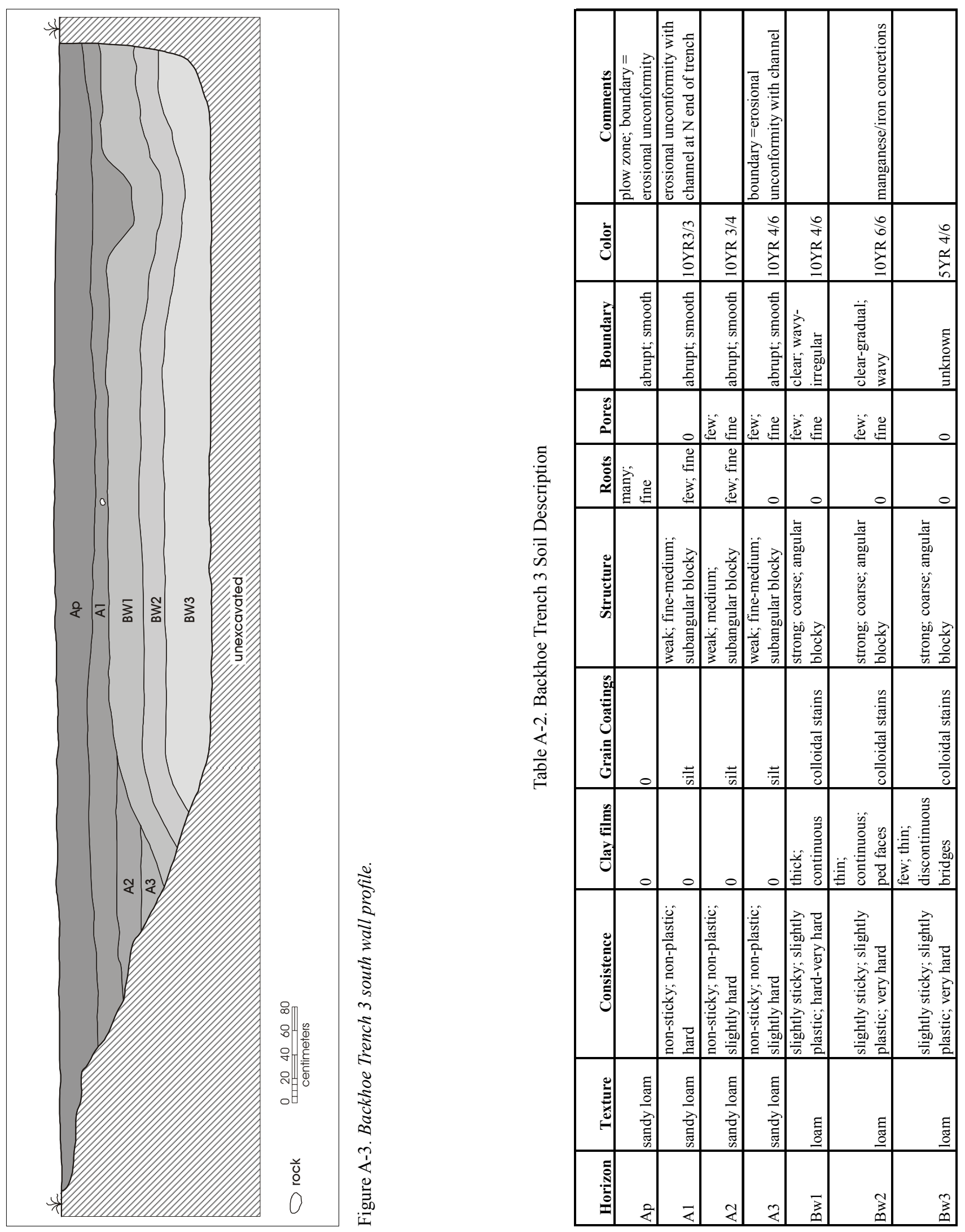

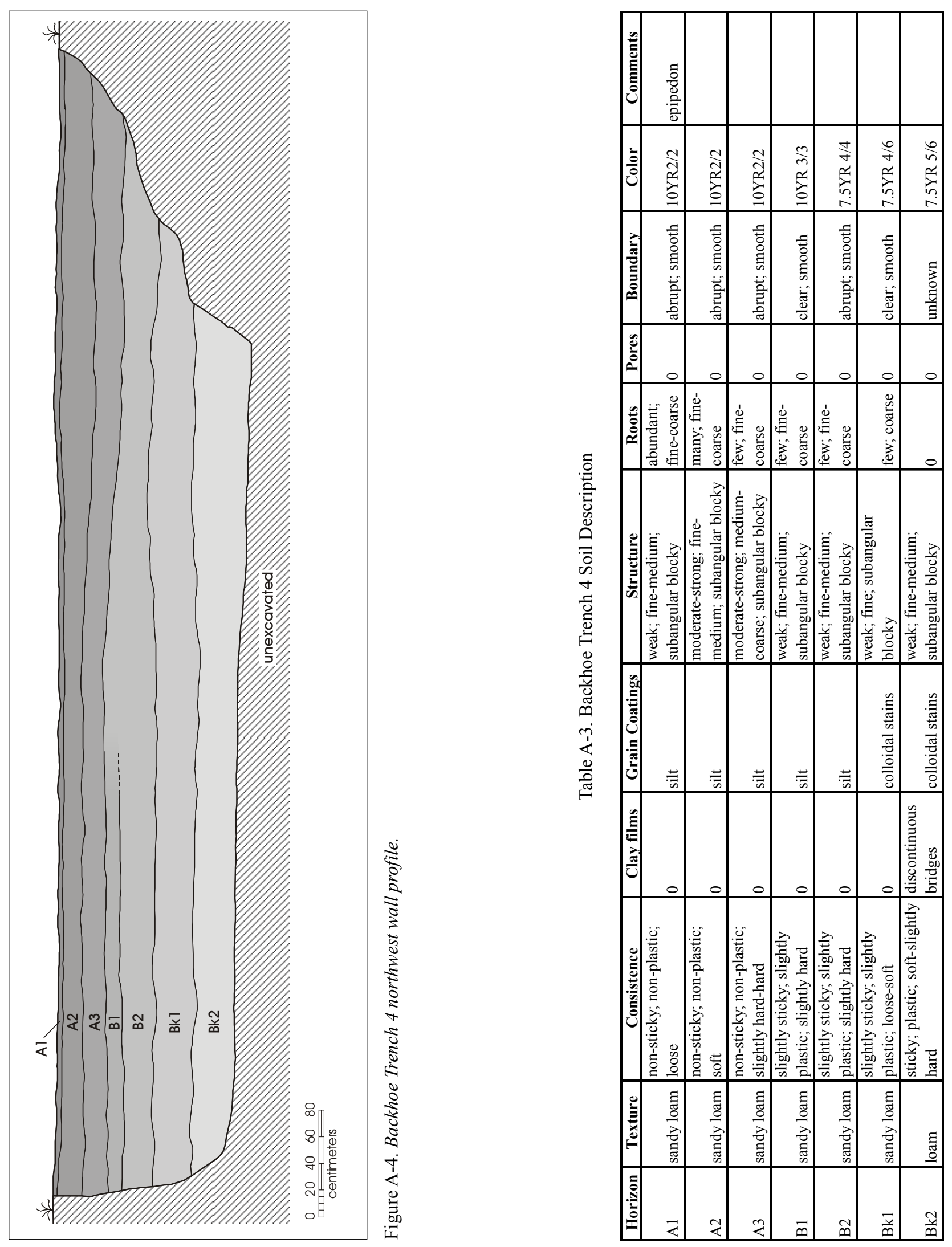
archaeological artifacts was identified in any other portion of this trench. The probable older origin of the Bk horizons in BHT 4 indicates that the upper portions of the profile have the highest probability to contain archaeological remains. It is unlikely that this area contains any significant, deeply buried archaeological deposits.

\section{BHT 5}

BHT 5 was $9.7 \mathrm{~m}$ long and was oriented $9^{\circ}-189^{\circ}$ from magnetic north. This trench was maximally $145 \mathrm{~cm}$ deep. The western wall of this trench was drawn (Figure A-5) but was not fully described. BHT 5 is situated on the identical landform to BHT 4 and also was placed to examine the potential for buried archaeological materials associated with a moderately robust surface presence of lithics. The soil sequence is very similar to that recorded in BHT 4. Three A horizons (A1, A2, and $\mathrm{A} 3)$ were present across the entire trench. An $\mathrm{AB}$ horizon was identified only in the northern portion of the trench. A single B horizon is present and conformably overlies a sequence of four Bk horizons. There are very few, fine $(<3 \mathrm{~mm})$ carbonate nodules present in the $\mathrm{A} 1, \mathrm{~A} 2, \mathrm{~A} 3, \mathrm{AB}$, and $\mathrm{B}$ horizons. Within the $\mathrm{Bk}$ soils, nodules are abundant and increase in size from $<2 \mathrm{~cm}$ in $\mathrm{Bk} 1$ to $<4$ $\mathrm{cm}$ in Bk4. The Bk horizons also appear redder than the overlying $\mathrm{A}, \mathrm{AB}$, and $\mathrm{B}$ horizons (equivalent colors to those presented in Table A-3 for BHT 4). No archaeological artifacts were identified in this trench.

\section{BHT 6}

BHT 6 was located in a similar position to the distribution of surface artifacts and inferred site boundary as BHTs 4 and 5. BHT 6 was $6.52 \mathrm{~m}$ long and was oriented $36^{\circ}-216^{\circ}$ from magnetic north. This backhoe trench was maximally $135 \mathrm{~cm}$ deep. The northwestern profile wall was drawn (Figure A-6) and the soils described (Table A-4). This trench was placed on a slightly different landform from BHTs 4 and 5. BHT 6 was located in an area that is part of a modern, shallow drainage, identifiable on aerial photographs from denser vegetation. This trench was situated slightly closer to the margin of the abandoned terrace of the Medina River, and was associated with some areas of surface erosion associated with that ephemeral drainage. The soils exposed in BHT 6 appear to be younger than those in BHT 4 or BHT 5. Unlike BHTs 4 and 5, there was minimal carbonate development in even the deepest soils and there were no rubified soils visible in the exposed trench walls. A sequence of four A horizons were present overlying one $\mathrm{AB}$ soil. Underneath the AB soil, two Bt horizons (Bt1 and Bt2) were

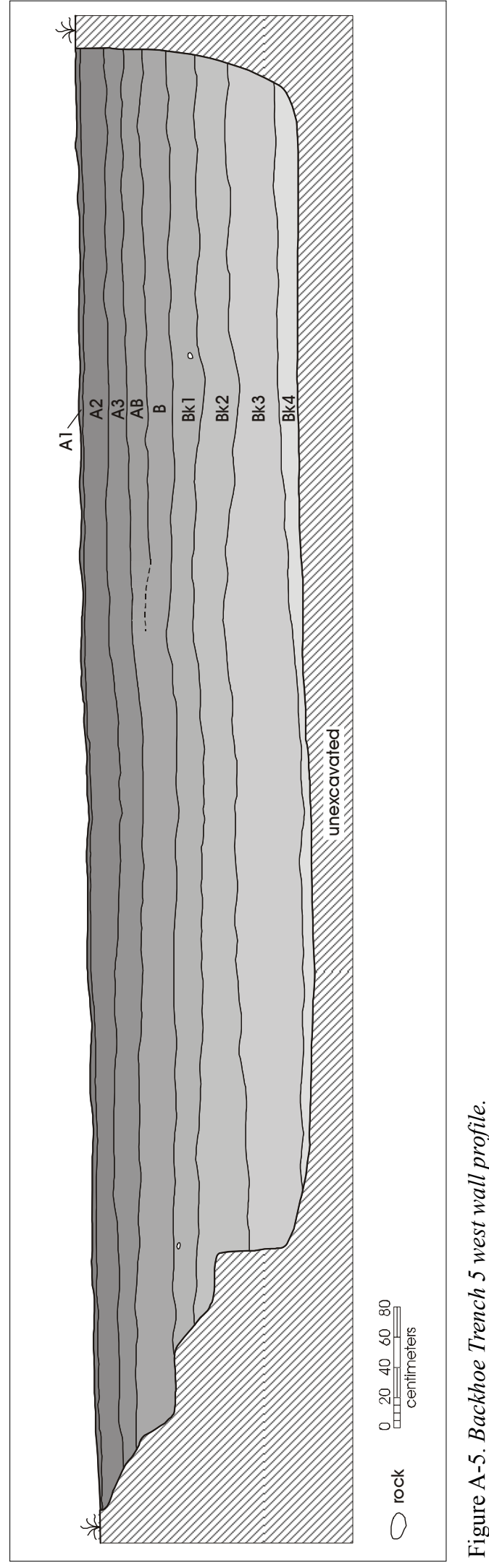



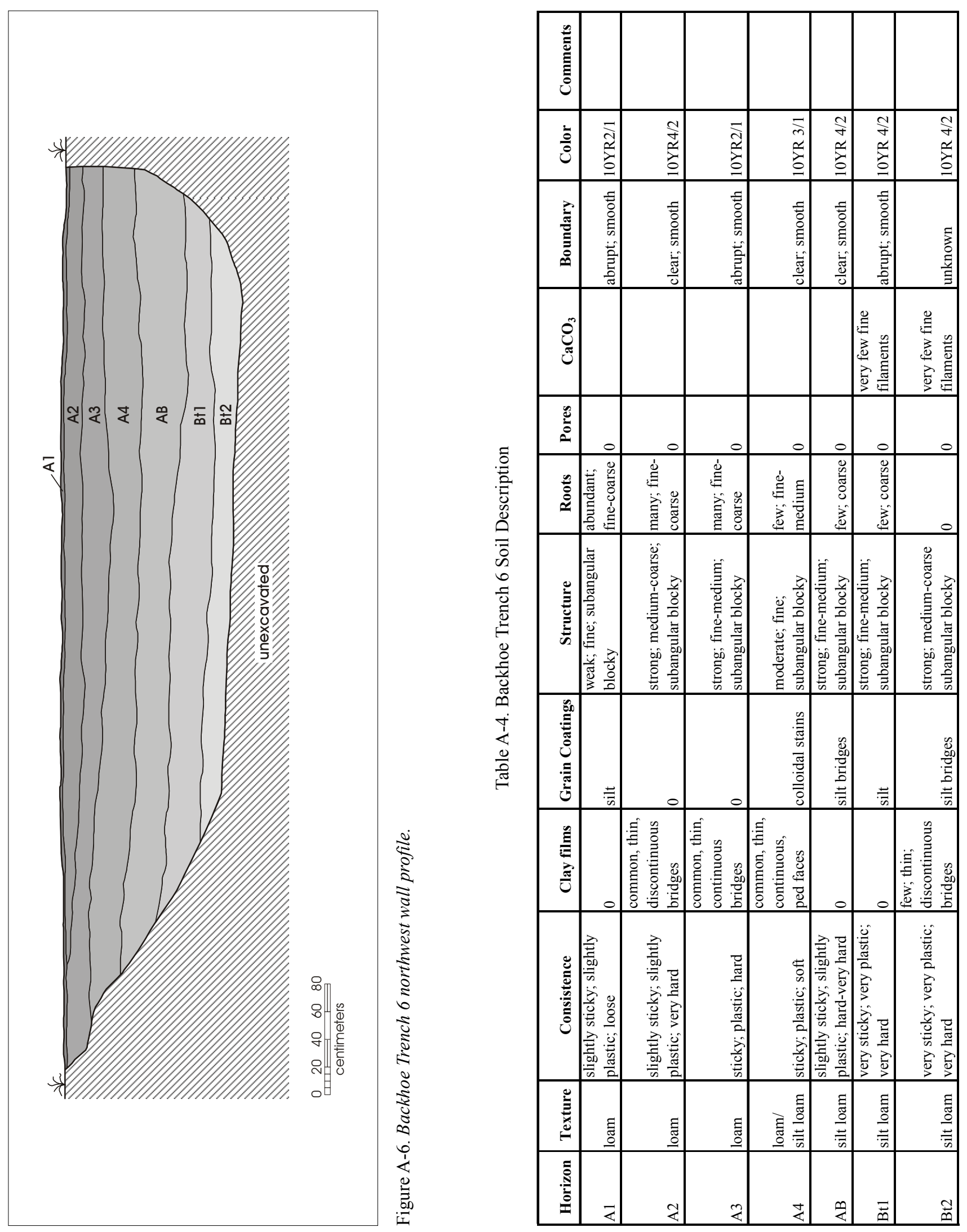
identified. They have a very noticeable clay bulge and contained very few, very fine $\mathrm{CaCO}_{3}$ filaments.

In addition to appearing much younger, the sediments in this setting contained significantly less sand (all loams and silt loams) compared with the other trenches investigated (dominated by sandy loams). The trench's geomorphic position within an ephemeral drainage of this upper abandoned high terrace of the Medina River indicates that these are recent deposits. The finer sediments, dominated by more silt than sand, indicate lower energy flow than the older events that produced the surrounding terrace deposits. The relatively young age of these soils suggests that they have the potential to contain deeply buried surfaces that could be associated with archaeological remains. However, the position within a channel also indicates a probability that such deposits could be in a secondary context or have been significantly affected by erosional events. This is not a location with a high probability to contain any intact, deeply buried archaeological sites.

\section{BHT 7}

This trench was situated nearer to the margin of the high abandoned terrace of the Medina River than any of the other trenches excavated in this geoarchaeological investigation. There is a shallow ephemeral drainage channel west of the northwestern end of this trench that is deeply incised at the edge of the terrace. The length of BHT 7 was $6.8 \mathrm{~m}$, it was oriented $162^{\circ}-342^{\circ}$ from magnetic north, and was maximally $145 \mathrm{~cm}$ deep. The east wall profile was drawn (Figure A-7) and an abbreviated set of soil descriptions recorded. There is a very thin ( $2-5 \mathrm{~cm}$ thick) sedimentary deposit (C) just underlying the epipedon (A) that is $<2 \mathrm{~cm}$ thick. This represents a very recent flood event. It may be associated with the floods of July or October of 2002. This is an unmodified $\mathrm{C}$ horizon with no evidence of pedogenesis. Underlying the $\mathrm{C}$ horizon are $\mathrm{Ab} 1$ and $\mathrm{Ab} 2$ that are relatively thin compared with the A horizons in BHTs 4, 5, and 6. The two buried A horizons are strongly developed with coarse, subangular blocky structure. There were few, very fine filaments in the $\mathrm{Ab} 2$ horizon. There was no visible carbonate development in the underlying $\mathrm{B}$ horizons. The $\mathrm{B} 1$ and $\mathrm{B} 2$ horizons in BHT 7 are the thickest B horizons encountered that are genetically related to the A horizons. At the base of the profile (the lowest approximately $40 \mathrm{~cm}$ ) are two $\mathrm{Bt}$ horizons that resemble those recorded in BHT 6. These two horizons had very few, fine $\mathrm{CaCO}_{3}$ filaments. No archaeological material was identified in this trench.

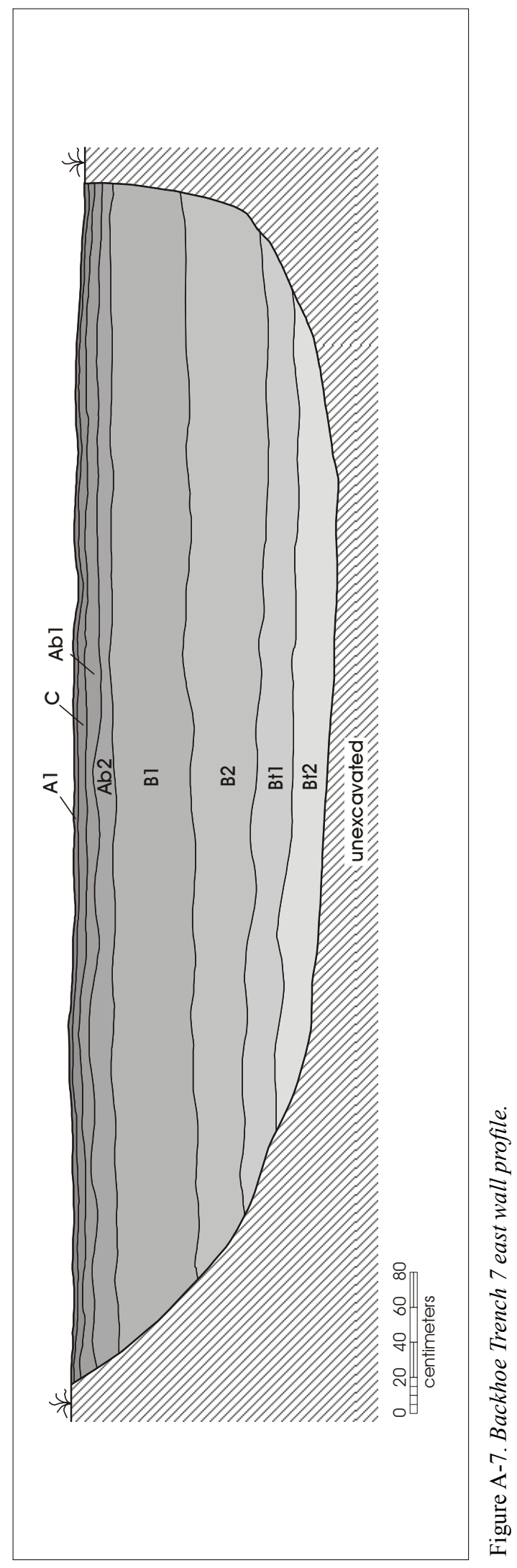


The lack of any Bk horizons and the presence of thick, genetically related soils suggests that the location of BHT 7 could contain deeply buried deposits of appropriate ages to contain archaeological sites. The position of this trench close to the margin of the high terrace, its location on the southeastern side of an ephemeral drainage, and the presence of a recent flood deposit (C horizon), suggests that the soils seen in the profile are more recently developed on sedimentary deposits than areas of equivalent elevation on this terrace surface. Although this is evidence of greater accretional deposition, it also indicates a high probability that cut and fill sequences are represented where older soils are present in the lower portions of other trench profiles (BHTs 4, 5, 8, and 9). As noted for BHT 6, the relatively young deposits are associated with periodic or ephemeral flood events. Buried archaeological materials in this area may be in a secondary context or affected by significant erosional events. It is unlikely that this area has a high potential to contain any significant, undisturbed, deeply buried archaeological deposits.

\section{BHT 8}

Examination of the profile of BHT 8 indicated that the soils are very similar to those recorded in BHTs 4 and 5. This trench was $7.78 \mathrm{~m}$ long and was oriented $23^{\circ}-203^{\circ}$ from magnetic north. BHT 8 was maximally $154 \mathrm{~cm}$ deep. The eastern wall was drawn (Figure A-8) and an abbreviated description of the soils was performed. BHT 8 contained a series of three $\mathrm{A}$ horizons that overlie an $\mathrm{AB}$ soil resting on top of a sequence of three exposed Bk horizons. Like BHTs 4 and 5, the recent solum $\mathrm{A} 1-\mathrm{A} 3$ and $\mathrm{AB}$ horizons are only $40-45 \mathrm{~cm}$ thick. The A1 horizon is a thin epipedon over a strongly developed A2 with coarse, subangular blocky structure. The A3 exhibits moderate to strong development and has a coarse structure. The AB unit is weakly to moderately developed, has fine-medium structure, and contains few and very small $(<5 \mathrm{~mm})$ calcium carbonate nodules. The three exposed Bk horizons are all significantly lighter in color and contain an increasing frequency of $\mathrm{CaCO}_{3}$ nodules. There are many carbonate nodules that are $<1 \mathrm{~cm}$ in the Bk1. Bk2 resembles the Bk1 horizon in BHTs 4 and 5. Nodules are common and $<2 \mathrm{~cm}$ in the $\mathrm{Bk} 2$ of BHT 8 . Bk3 has abundant nodules that are $<3 \mathrm{~cm}$ in maximum diameter. As noted for BHT 4, the Bk horizons suggest the presence of an older soil formation regime that is capped by the modern solum $\mathrm{A} 1-\mathrm{A} 3$ and the $\mathrm{AB}$ horizons. There were no archaeological artifacts encountered within the trench profiles. Depending on the age of the lower Bk units, prehistoric materials would most likely be confined to the upper portion of the profile and this area has a low potential to contain deeply buried archaeological remains.

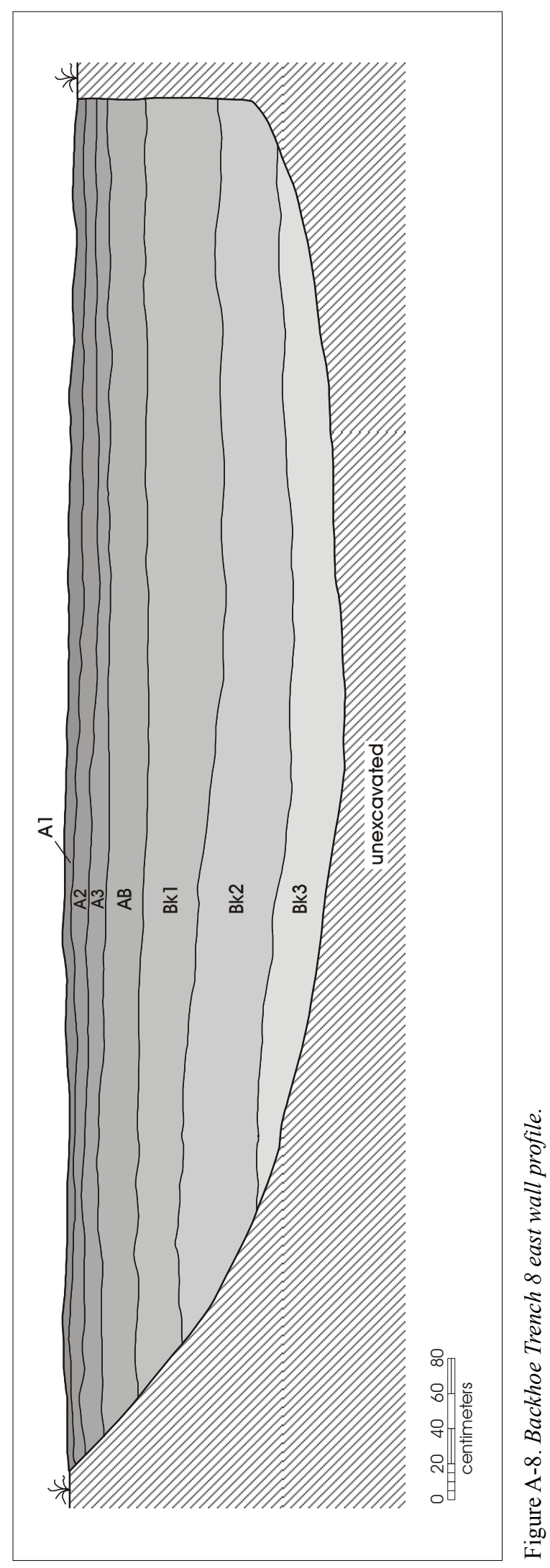




\section{BHT 9}

BHT 9 was located southeast of BHT 8 in a similar geomorphic position to BHT 8. BHT 9 also was situated between to areas of relatively dense surface and near surface prehistoric archaeological remains identified during archaeological testing. This trench was $7.4 \mathrm{~m}$ long, oriented $98^{\circ}-278^{\circ}$ from magnetic north, and was maximally $135 \mathrm{~cm}$ deep. The southern wall was drawn (Figure A-9) and a full soil description was recorded (Table A-5). The soils in BHT 9 are similar to those in BHT 8. A series of four A horizons are maximally $30 \mathrm{~cm}$ deep and rest on an $\mathrm{AB}$ unit that contains few, very fine filaments. Underlying the AB soil are two Bk horizons that are moderately developed with coarse prismatic structure. Underneath the Bk2, a completely whitened $\mathrm{K}$ horizon was exposed in the lowermost $5-7 \mathrm{~cm}$ of the profile that contains abundant soft carbonate masses that are $<4 \mathrm{~cm}$ in diameter. No evidence of prehistoric or historic archaeological materials or features was visible in this trench. As noted for BHTs 4, 5, and 8, the older Bk soils indicate a low probability that deeply buried archaeological remains may be present in this vicinity.

\section{Geoarchaeological Conclusions}

Examination of a series of nine backhoe trenches provided minimal evidence of buried archaeological materials. The most robust record is from BHT 1 in the vicinity of the ruins of the ranch structure. A single prehistoric flake and several sherds of historic ceramic, bone fragments, and one piece of metal were identified in both walls of BHT 1 . All of these materials were associated exclusively with the plow zone. Older Bt soils underlying the A horizon in this trench and in BHTs 2 and 3 are separated from the modern solum by erosional unconformities and are likely too old to contain any deeply buried prehistoric remains.

These three backhoe trenches (BHTs 1, 2, and 3) are situated on higher terrace deposits that are separated from the other backhoe trenches by a break in slope to the south. Soils in this area are similar to the oldest group of soils seen during geoarchaeological investigations of the Starbright Project to the northeast of the current project area. The higher position indicates that the $\mathrm{Bw}$ soils in BHTs 1, 2, and 3 are probably the oldest sediments examined in association with archaeological remains of 41BX274. No precise age assignment is possible without some form of chronometric determination. However, the amount of soil formation in the $\mathrm{Bw}$ units would not be inconsistent with a Pleistocene age. Currently there are no means of precisely dating the lower sedimentary units in these trenches. They are associated with unconformable contact with overlying organically enriched A horizons. These deposits increase in thickness downslope on each succeeding lower terrace surface. The evidence of a channel cut in BHT 3 clarifies that the A horizon sediments are associated with cut and fill sequences and these soils are not genetically related to the underlying $\mathrm{Bw}$ units. It appears that any historic or prehistoric archaeological remains will be associated only with the upper units of the solum. There is a very low probability that any deeply buried archaeological deposits are present on this landform.

The only exception to the presence of shallow, recent soils overlying much older soils was identified in the eastern end of BHT 3. Profiling of the Bt soils indicated the presence of an ancient drainage channel and the A horizon deposits are much thicker at this end of the trench. Aerial imagery indicates that a channel meander is present to the east of the inferred boundary of 41BX274. The deeper sediments that filled the channel meander do have a probability to contain buried archaeological deposits. It appears that the highest probability for intact historic or prehistoric remains would be from unplowed contexts adjacent to the western margin of this plowed field. However, much of this area has probably been cultivated in the past (Taylor et al. 1962:18, Map 85).

The other trenches were placed on a terrace surface that is younger than the surface where BHTs 1, 2, and 3 were excavated. Backhoe Trenches 4, 5, 8, and 9 present similar sedimentary and soil formation histories. These trenches contained older Bk horizons (less well-developed and younger than the Bt soils in BHTs 1,2, and 3) that are likely not genetically related to the upper horizons. All of these trenches possess relatively thin, but well-developed $\mathrm{A}$ horizons over an $\mathrm{AB}$ horizon or thin $\mathrm{B}$ horizons. There is a low probability that the older Bk soils may contain deeply buried archaeological materials. Two flakes were recovered from one portion of BHT 4. No other evidence of archaeological deposits was identified in any other trench. Shovel testing in these areas identified artifacts only in the uppermost portions of the A horizons. The Bk soils appear unrelated to the A horizons that contained archaeological artifacts in BHT 4 and in the shovel tests. However, no chronometric dates are currently available on these soils. Based on this investigation, it appears unlikely that the Bk soils may contain older archaeological remains. Dating of these older soils and comparisons with more thoroughly studied areas of the Leon Creek and Medina River drainages where deeply buried archaeological materials have been recorded would help clarify this ambiguity. 

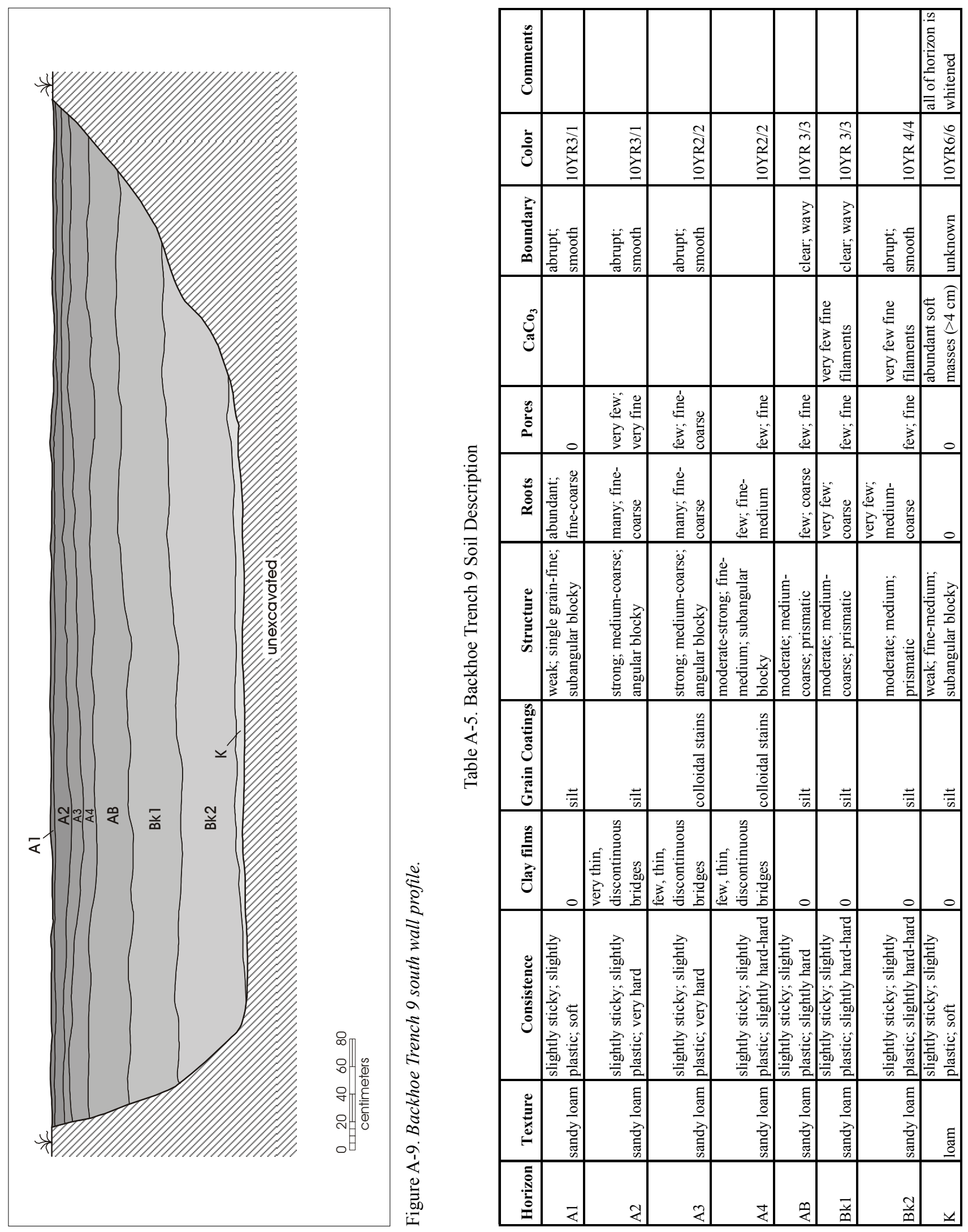
BHTs 6 and 7 contained younger soils and there was no evidence of the older Bk horizons in these trenches. Both of these trenches appear to have been subject to cut and fill erosional events. Although unconformities were not exposed in these trenches, the absence of the BK unit seen in BHTs $4,5,8$, and 9 indicates those soils have been removed. Both BHTs 6 and 7 are associated with modern ephemeral drainage features. Although it is possible that these locations may contain more deeply buried archaeological deposits, they are very likely to represent secondary deposition or remains that have been disturbed by alluvial processes. There is a very low probability that the areas adjacent to BHTs 6 and 7 contain significant buried archaeological resources. 


\section{References Cited}

Birkeland, P. W.

1984 Soils and Geomorphology. Oxford University Press, New York.

\section{Soil Survey Staff}

1993 Soil Survey Manual. U.S. Department of Agriculture Handbook No. 18. U.S. Department of Agriculture. U.S. Government Printing Office, Washington, D.C.

Taylor, F. B., R. B. Hailey, and D. L. Richmond

1962 Soil Survey: Bexar County, Texas. U.S. Department of Agriculture, Soil Conservation Service, in cooperation with the Texas Agricultural Experiment Station. 